\title{
Development and validation of a conceptual survey instrument to evaluate students' understanding of thermodynamics
}

\author{
Benjamin Brown and Chandralekha Singh॰ \\ Department of Physics and Astronomy, University of Pittsburgh, Pittsburgh, Pennsylvania 15260, USA
}

(Received 4 January 2020; accepted 8 January 2021; published 29 January 2021)

\begin{abstract}
We discuss the development and validation of a conceptual multiple-choice survey instrument called the survey of thermodynamic processes and first and second laws (STPFaSL) suitable for introductory physics courses. The survey instrument uses common student difficulties with these concepts as resources in that the incorrect answers to the multiple-choice questions were guided by them. After the development and validation of the survey instrument, the final version was administered at six different institutions. It was administered to introductory physics students in various traditionally taught calculus-based and algebrabased classes in paper-pencil format before and after traditional lecture-based instruction in relevant concepts. We also administered the survey instrument to upper-level undergraduates majoring in physics and Ph.D. students for benchmarking and for content validity and compared their performance with those of introductory students for whom the survey is intended. We find that although the survey instrument focuses on thermodynamics concepts covered in introductory courses, it is challenging even for advanced students. A comparison with the base line data on the validated survey instrument presented here can help instructors evaluate the effectiveness of innovative pedagogies designed to help students develop a solid grasp of these concepts.
\end{abstract}

DOI: 10.1103/PhysRevPhysEducRes.17.010104

\section{INTRODUCTION AND BACKGROUND}

\section{A. Multiple-choice surveys}

Major goals of college introductory physics courses for life science, physical science, and engineering majors include helping all students develop functional understanding of physics and learn effective problem-solving and reasoning skills [1-11]. Validated conceptual multiplechoice physics survey instruments administered before and after instruction in relevant concepts can be useful tools to gauge the effectiveness of curricula and pedagogies in promoting robust conceptual understanding. When compared to free-response problems, multiple-choice problems can be graded efficiently and results are easier to analyze statistically for different instructional methods and/ or student populations. However, multiple-choice problems also have some drawbacks. For example, students may select the correct answers with erroneous reasoning or explanation. Also, students cannot be given partial credit for their responses.

The multiple-choice survey instruments have been used as one tool to evaluate whether research-based instructional

Published by the American Physical Society under the terms of the Creative Commons Attribution 4.0 International license. Further distribution of this work must maintain attribution to the author(s) and the published article's title, journal citation, and DOI. strategies are successful in significantly improving students' conceptual understanding of these concepts. For example, the Force Concept Inventory is a conceptual multiple-choice survey instrument that helped many instructors recognize that introductory physics students were often not developing a functional understanding of force concepts in traditionally taught courses (primarily using lectures) even if students could solve quantitative problems assigned to them by using a plug-and-chug approach [12-14]. Other conceptual survey instruments at the introductory physics level in mechanics and electricity and magnetism have also been developed, including survey instruments for kinematics represented graphically [15], energy and momentum [16], rotational and rolling motion [17,18], electricity and magnetism [19-23], circuits [24] and Gauss's law [25,26].

In thermodynamics, existing conceptual survey instruments include the following: (i) Heat and Temperature Conceptual Evaluation (HTCE) [27,28] that focuses on temperature, phase change, heat transfer, thermal properties of materials; (ii) Thermal Concept Evaluation (TCE) $[29,30]$ that also focuses on similar concepts to HTCE; (iii) Thermal Concept Survey (TCS) [31] that focuses on temperature, heat transfer, ideal gas law, first law of thermodynamics, phase change, and thermal properties of materials; (iv) Thermodynamics Concept Inventory (TCI) [32] that focuses on concepts in engineering thermodynamics courses; and (v) Thermal and Transport Concept 
Inventory: Thermodynamics (TTCI:T) [33] that also focuses on concepts in engineering thermodynamics courses. Despite these five conceptual survey instruments on introductory thermodynamics, there is a lack of researchvalidated survey instrument that focuses on the basic concepts related to thermodynamic processes and the first and second laws covered in introductory physics courses. Therefore, we developed and validated [34-36] a 33-item conceptual multiple-choice survey instrument on these concepts called the survey of thermodynamic processes and first and second laws (STPFaSL). We note that the overlap of the STPFaSL content with HTCE and TCE is minimal. Moreover, although there is overlap between TCI, TTCI:T and STPFaSL concepts, contexts used in TCI and TTCI:T are engineering oriented and therefore, these surveys are unlikely to be used by introductory physics instructors. Finally, TCS is for introductory physics courses and covers some common content to STPFaSL but TCS is a much broader survey and has a major emphasis on temperature, the ideal gas law, phase change, and thermal properties of materials, content that are not explicitly the focus of the STPFaSL instrument.

\section{B. Inspiration from other prior investigations on student understanding of thermodynamics}

Prior research has not only focused on the development and validation of multiple-choice surveys to investigate students' conceptual understanding of various thermodynamic concepts, but many investigations have focused on student understanding of thermodynamics without using multiple-choice surveys [37-62]. Some of these investigations use conceptual problems to probe students understanding that ask students to explain their reasoning. These investigations were invaluable in the development of the STPFaSL instrument. For brevity, below, we only give a few examples of studies that were used as a guide and from which open-ended questions were used in the earlier stages of the development of the multiple-choice questions for the STPFaSL instrument.

Loverude et al. [38] investigated student understanding of the first law of thermodynamics in the context of how students relate work to the adiabatic compression of an ideal gas. For example, in one problem used to investigate student understanding in their study, students were asked to consider a cylindrical pump (diagram was provided) containing one mole of an ideal gas. The piston fit tightly so that no gas could escape. Students were asked to consider friction as being negligible between piston and the cylinder. The piston was thermally isolated from the surrounding. In one version of the problem, students were asked what will happen to the temperature of the gas and why if the piston is quickly pressed inward. Another type of problem posed to students in the same research involved providing a cyclic process on a $P V$ diagram in which part of the cyclic process was isothermal, isobaric, and isochoric. Students were asked whether the work done in the entire cycle was positive, negative, or zero and explain their reasoning.

Another investigation of students' reasoning of heat, work, and the first law of thermodynamics in an introductory calculus-based physics course by Meltzer et al. [39] asked several conceptual problems some of which involved the $P V$ diagrams. For example, one problem in their study involved two different processes represented on the $P V$ diagram that started at the same point and ended at the same point. Students were asked to compare the work done by the gas and the heat absorbed by the gas in the two processes and explain their reasoning for their answers.

In another investigation focusing on student understanding of the ideal gas law using a macroscopic perspective, Kautz et al. [40] asked several conceptual problems. For example, in one problem in which a diagram was provided, three identical cylinders are filled with unknown quantities of ideal gases. The cylinders are closed with identical frictionless pistons. Cylinders $A$ and $B$ are in thermal equilibrium with the room at $20^{\circ} \mathrm{C}$, and cylinder $C$ is kept at a temperature of $80^{\circ} \mathrm{C}$. The students were asked whether the pressure of the nitrogen gas in cylinder $A$ is greater than, less than, or equal to the pressure of the hydrogen gas in cylinder $B$, and whether the pressure of the hydrogen gas in cylinder $B$ is greater than, less than, or equal to the pressure of the hydrogen gas in cylinder $C$. Students were asked to explain their reasoning.

Another investigation by Cochran et al. [41] focused on student conceptual understanding of heat engines and the second law of thermodynamics. For example, in one question students were provided the diagram of a proposed heat engine (including the temperatures of the hot and cold reservoirs, the heat absorbed from the hot reservoir, and the heat flow to the cold reservoir as well as the work done) and asked if the device as shown could function and why. In another investigation, Bucy et al. [42] focused on student understanding of entropy in the context of comparison of ideal gas processes. For example, students were asked to compare the change in entropy of an ideal gas in an isothermal expansion and free expansion into a vacuum and also explain whether the change in entropy of the gas in each case is positive, negative, or zero in each case and why. In another investigation by Christensen et al. [43], students' ideas regarding entropy and the second law of thermodynamics in an introductory physics course were studied. They found that students struggled in distinguishing between entropy of the system and the surrounding and had great difficulty with spontaneous processes. Another investigation by Smith et al. [44] focused on student difficulties with concepts related to entropy, heat engines, and the Carnot Cycle and how student understanding can be improved.

\section{Goal of this paper}

Here we discuss the development and validation of the STPFaSL instrument related to thermodynamic processes 
and the first and second laws covered in introductory physics courses in which these prior investigations were used as a guide. We present average base line data from the STPFaSL survey instrument from traditional lecture-based introductory physics courses (along with the STPFaSL survey instrument and key in Ref. [63]) so that instructors in courses covering the same concepts but using innovative pedagogies can compare their students' performance with those provided here to gauge the relative effectiveness of their instructional design and approach. The data were collected from six different higher education institutions in the U.S. (four research-intensive large state universities and two colleges). Since the data from different institutions for the same type of course (e.g., calculus-based introductory physics course) are similar, average combined data from different institutions for the same course type are presented.

\section{STPFaSL INSTRUMENT DEVELOPMENT AND VALIDATION}

The thermodynamics survey instrument development and validation process was analogous to those for the earlier conceptual survey instruments developed by our group $[16,18,21,22,25]$. Our process is consistent with the established guidelines for test development and validation [34-36] using the classical test theory (CTT). According to the standards for the multiple-choice test (survey) instrument design, a high-quality test instrument has five characteristics: reliability, validity, discrimination, good comparative data, and suitability for the population [34-36]. Moreover, the development and validation of a well-designed survey instrument is an iterative process that should involve recognizing the need for the survey instrument, formulating the test objectives and scope for measurement, constructing the test items, performing content validity and reliability check, and distribution [34-36]. Below we describe the development and validation of the STPFaSL instrument.

\section{A. Development of test blueprint}

Before developing the STPFaSL instrument items, we first developed a test blueprint to provide a framework for deciding the desired test attributes. The test blueprint provided an outline and guided the development of the test items. The development of the test blueprint entailed formulating the need for the survey instrument, determining its scope, format, and testing time of the test as well as determining the weights of different subtopics consistent with the scope and objective of the test. The specificity of the test plan helped to determine the extent of content covered and the complexity of the questions.

As noted in the introduction, despite the existence of several thermodynamics survey instruments at the introductory level [27-33], there is no research-validated survey instrument that focuses on the basics of thermodynamic processes and the first and second laws of thermodynamics covered in the introductory physics courses. Therefore, we developed and validated the STPFaSL instrument focusing on content covered in introductory physics courses. The STPFaSL instrument is a multiple-choice conceptual survey on thermodynamic processes and the first and second laws covered in both calculus-based and algebra-based introductory physics courses. It can be used to measure the effectiveness of traditional and/or research-based approaches for helping introductory students learn thermodynamics concepts covered in the survey for a group of students. Specifically, the survey instrument is designed to be a low stakes test to measure the effectiveness of instruction in helping students in a particular course develop a good grasp of the concepts covered and is not appropriate for high stakes testing. The STPFaSL survey instrument can be administered before and after instruction in relevant concepts to evaluate introductory physics students' understanding of these concepts and to evaluate whether innovative curricula and pedagogies are effective in reducing the difficulties. With regard to the testing time, this survey is designed to be administered in one 40-50 min long class period although instructors should feel free to give extra time to their students as they deem appropriate. The survey can also be administered in small groups in which students can discuss the answers with each other before selecting an answer for each item. With regard to the weights of different subtopics consistent with the scope and objective of the test, we browsed over introductory physics textbooks, consulted with seven faculty members and looked at the kinds of questions they asked their students in homework, quizzes, and exams before determining it as discussed below.

\section{B. Formulating test objectives and scope}

We focused the survey content on thermodynamic processes and first and second laws that is basic enough that the survey instrument is appropriate for both algebrabased and calculus-based introductory physics courses in which these thermodynamics topics are covered. We also made sure that the survey instrument has questions at different levels of cognitive achievement [34-36].

In order to formulate test objectives and scope pertaining to thermodynamic processes and first and second laws, the survey instrument development started by consulting with seven instructors who regularly teach calculus-based and algebra-based introductory physics courses in which these topics in thermodynamics are covered. We asked them about the goals and objectives they have when teaching these topics and what they want their students to be able to do after instruction in relevant concepts. In addition to perusing through the coverage of these topics in several algebra-based and calculus-based introductory physics textbooks, we browsed over homework, quiz, and exam problems that these instructors in introductory algebra-based and calculus-based courses at the University of Pittsburgh 
TABLE I. Topics by item number. Pitt physics faculty members and the Pitt physics education research (PER) group independently reached a consensus on identifying topics involved in each problem. An " $\mathrm{M}$ " indicates that a concept was mentioned but not required to solve the problem in the opinion of content experts. An " $\mathrm{R}$ " indicates that a concept is required to solve the problem. An "I" indicates that a topic is implicitly required though not explicitly asked for or mentioned. For instance, generally, if a student must reason about a $P V$ diagram to infer the heat transfer to a system, the concept of "work" is implicitly required.

1233456789101112131415161718192021222324252627282930313233

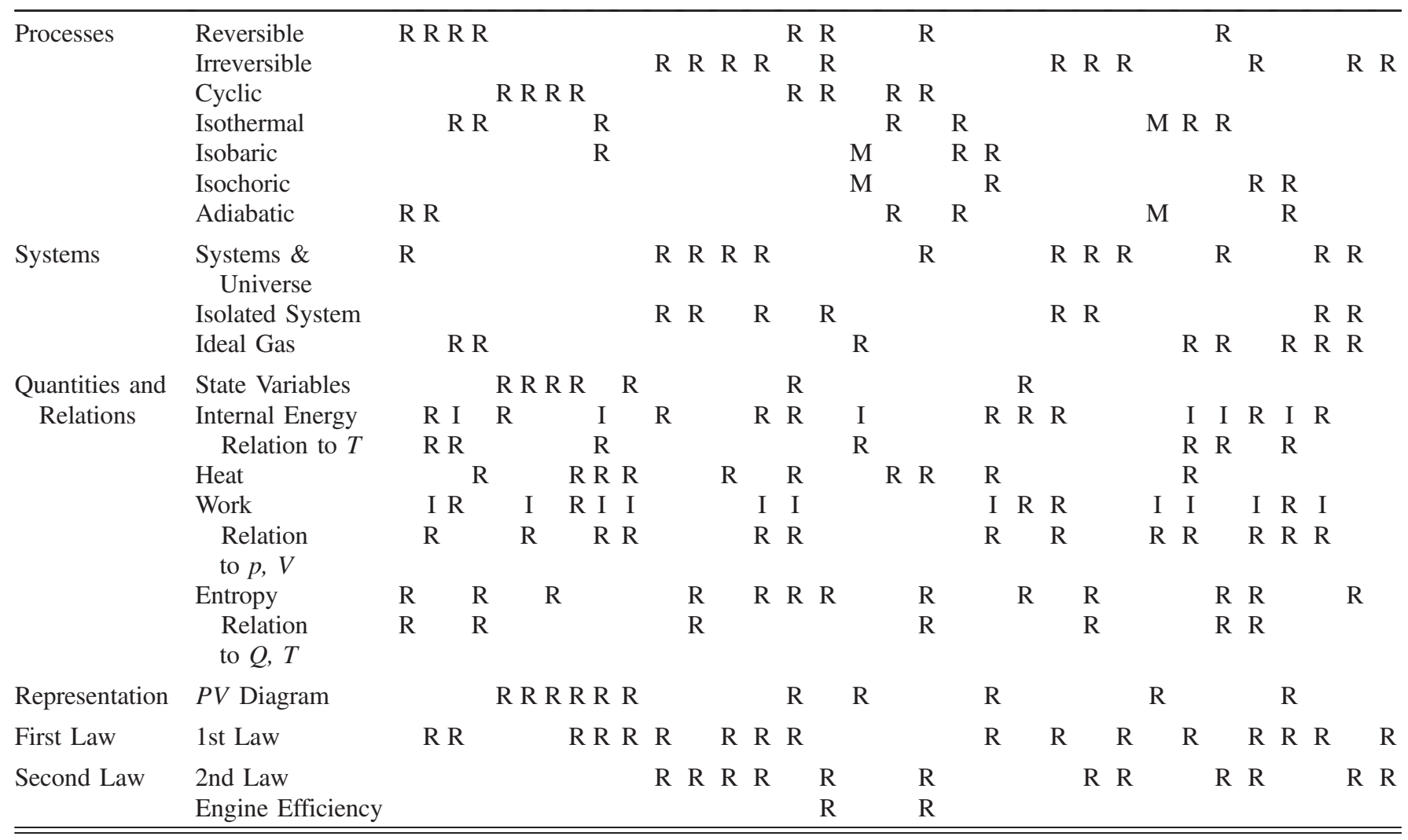

(Pitt) had typically given to their students in the past before determining the test objective and scope of the test in terms of the actual content and starting the design of the questions for the instrument. The preliminary distribution of questions from various topics was discussed and iterated several times, and finally agreed upon with seven introductory physics course instructors at Pitt.

\section{Concepts covered}

Table I shows that the broad categories of topics covered in the survey are processes, systems, quantities and relations, representation, the first law of thermodynamics, and the second law of thermodynamics. The processes category includes items which require understanding of thermodynamic constraints such as whether a process is reversible, isothermal, isobaric, or adiabatic. Also included are problems involving irreversible and cyclic processes. We note that these different processes are not necessarily exclusive, e.g., one can consider an isothermal reversible process. The systems category includes items involving knowledge of the distinction between a system and the Universe, items involving subsystems or an isolated system. The systems category also includes items in which a student could make progress by making use of the fact that the system is an ideal gas (e.g., for an ideal gas, the internal energy and temperature have a simple relationship which can be used to solve a problem). Quantities and relations includes survey items specific to a quantity such as internal energy, work, heat, entropy, and their quantitative relationships. For example, the relationship between work and the area under the curve on a $P V$ diagram is tested in several problems. The representation category includes items in which a process is represented on a $P V$ diagram. Finally, the last two categories include items requiring the first law and second law of thermodynamics. We classified questions about heat engines into the second law of thermodynamics category (although heat engines involve both the first and second laws) due to the particular focus of the only two problems on the survey that touched upon heat engines.

\section{Development of multiple-choice test items}

As noted, the selection of topics for the questions included consultation with 7 instructors who teach 
introductory thermodynamics (some of whom had also taught upper-level thermodynamics) about their goals and objectives and the types of conceptual and quantitative problems they expected their students in introductory physics courses to be able to solve after instruction. The wording of the questions took advantage of the existing literature regarding student difficulties in thermodynamics, input from students' written responses and interviews and input from physics instructors who teach these topics. However, most questions on the survey require reasoning, and there are very few questions which can be answered simply by rote memory.

Since we wanted instructors to be able to administer STPFaSL instrument in one 40-50 min-long class period, the final version of the survey has 33 multiple-choice items (see Ref. [63]). Each question has one correct choice and four alternative or incorrect choices. We find that most students are able to complete the survey in one class period. We note, however, that instructors can choose to give longer time to their students as they see fit.

In developing good alternative choices for the multiple-choice conceptual problems, we first took advantage of prior work on student difficulties with relevant topics in thermodynamics [37-62]. To investigate student difficulties further in introductory physics courses at Pitt, we administered sets of free-response questions to students in various introductory physics courses after traditional instruction in which students had to provide their reasoning. Many of these questions were similar to the type of open-ended conceptual free-response problems that were summarized in introductory section from prior studies. While many of the findings replicated what was found in prior investigations, the responses to these open-ended questions were summarized and categorized to understand the prevalence of various difficulties at Pitt. These findings will be presented in future publications. In addition to leveraging the findings of prior research on students' conceptual understanding of these concepts [38-62], the process of administering some open-ended questions at Pitt was helpful in order to internalize the findings of prior research and develop good alternatives for the questions in the survey based upon common difficulties.

Moreover, as part of the development and validation of the survey, the concepts involved in the STPFaSL instrument and the wording of the questions have been independently evaluated by four physics faculty members who regularly teach thermodynamics at Pitt (in addition to the feedback from members of the PER group at Pitt) and iterated many times until agreed upon. Moreover, two faculty members from other universities who are experts in thermodynamics PER provided invaluable feedback several times to improve the quality of the survey questions.

\section{E. Refinement of test items based upon student interviews}

We also interviewed individual students using a thinkaloud protocol at various stages of the survey instrument development to develop a better understanding of students' reasoning processes when they were answering the freeresponse and multiple-choice questions. Within this interview protocol, students were asked to talk aloud while they answered the questions so that the interviewer could understand their thought processes. Individual interviews with students during development of the survey instrument were useful for an in-depth understanding of the mechanisms underlying common student difficulties and to ensure that students interpreted the questions appropriately. Based upon the student feedback, the questions were refined and tweaked.

We note that during the initial stage of the development and validation process, 15 students in various algebra-based and calculus-based physics courses participated in the think-aloud interviews. Ten graduate students and undergraduates who had learned these concepts in an upper-level thermodynamics and statistical mechanics course were also interviewed. The purpose of involving some advanced students in these interviews was to compare the thought processes and difficulties of the advanced students in these courses with introductory students for benchmarking purposes. This type of benchmarking has been valuable to illustrate growth of student understanding in prior research [64]. We found that students' reasoning difficulties across different levels are remarkably similar except in a few instances, e.g., advanced students were more facile at reasoning with PV diagrams than introductory students. Moreover, nine additional interviews, drawn from a pool of students in introductory courses who were currently enrolled in a second semester course after finishing the first semester course (in which mechanics and thermodynamics were covered), were conducted with the STPFaSL instrument when it was close to its final form to tweak the wording of the questions further.

\section{F. Refinement of test items based upon instructor feedback}

We note that in addition to developing good distractors by giving free-response questions to students and interviewing students with different versions of the multiplechoice survey, ongoing expert feedback was essential. We not only consulted with faculty members initially before the development of the survey questions, but also iterated different versions of the open-ended and multiple-choice questions with several instructors at Pitt at various stages of the development of the survey. Four instructors at Pitt reviewed the different versions of the STPFaSL instrument several times to examine its appropriateness and relevance for introductory algebra-based or calculus-based courses and to detect any possible ambiguity in item wording. Also, 


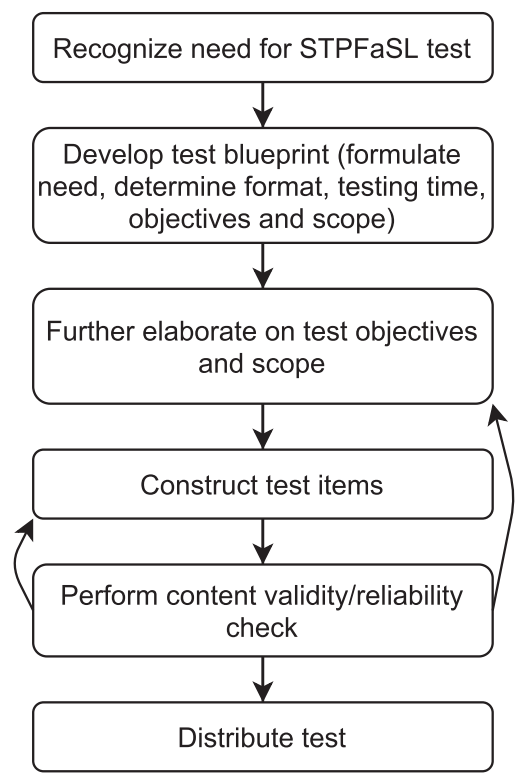

FIG. 1. A schematic diagram of the STPFaSL instrument development process.

as noted, two faculty members from other universities who have been extensively involved in physics education research in thermodynamics also provided extremely valuable suggestions and feedback to fine-tune the multiplechoice version many times into the final form.

\section{G. Fine-tuning of the survey based upon statistical analysis}

On the STPFaSL instrument, the incorrect choices for each item often reflect students' common alternative conceptions to increase the discriminating properties of the item. Having good distractors as alternative choices is important so that the students do not select the correct answer for the wrong reason. Statistical analysis based upon classical test theory (to be discussed in the next section) was conducted on different versions of the multiple-choice survey instrument as the items were being refined, which helped fine-tune the items further. A schematic diagram of the STPFaSL instrument development process is shown in Fig. 1.

\section{H. Students' knowledge of survey content before introductory physics}

Discussions with students suggested that introductory physics students had some knowledge of thermodynamics from high school physics and chemistry courses, college chemistry courses, and/or medical school entrance exam preparatory materials. Therefore, although a majority of the open-ended questions were administered after traditional instruction in relevant concepts, we wanted to gain some insight into what introductory physics students knew about the relevant thermodynamic concepts in the survey instrument from previous courses before they learned about them in that course. Therefore, we administered the following brief open-ended survey as bonus questions in a midterm exam (for which students obtained extra credit) to students in the first semester of an algebra-based physics course in which the instructor had started discussing thermodynamics, introducing concepts such as temperature, heat capacity, thermal expansion, and heat transfer, but there was no instruction in the first and second laws of thermodynamics:

(1) Describe the first law of thermodynamics in your own words.

(2) Describe the second law of thermodynamics in your own words.

(3) Describe other central or foundational principles of thermodynamics (other than the first and second laws).

Of the 207 students, 134 chose to respond to at least some of these bonus questions (65\%). Their responses about the laws of thermodynamics and the difficulties they reveal are shown in Table II. In particular, we find that for the first law question, while about half of the students stated that energy is conserved, e.g.,"Energy cannot be created or destroyed" (52\%), only $5 \%$ made a statement that includes heat transfer as part of the conservation law. Another frequent

TABLE II. Responses of introductory physics students in an algebra-based course about the laws of thermodynamics based upon what they had learned in previous courses before instruction in these laws in that physics course. The percentages are determined by taking into account only the students who attempted to answer the bonus questions.

\begin{tabular}{llr}
\hline \hline Topic & \multicolumn{1}{c}{ Claim } & Frequency $(\%)$ \\
\hline First law & Energy is conserved (no mention of heat) & 52 \\
& Energy is conserved, with heat somehow incorporated & 5 \\
& Heat is conserved & 15 \\
& Total first lawlike responses & 72 \\
Second law & Entropy increases always & 14 \\
& Entropy increases under some conditions & 4 \\
& Energy becomes unusable & 10 \\
& Heat flows from warmer objects to cooler objects & 23 \\
& Total second lawlike responses & 51 \\
\hline \hline
\end{tabular}


TABLE III. The average performance of different groups on all of the 33 items taken together or a subset of items and the number $(N)$ of students who participated in the survey in each group. Upper-under consists of advanced undergraduate students who had learned the relevant concepts in an upper-level thermodynamics and statistical mechanics course, Ph.D. student Ind. (where ind. stands for individual) consists of entering physics Ph.D. students in their first semester of the Ph.D. program. Ph.D. student pairs consist of small groups (20 pairs and one group with 3) of Ph.D. students discussing and responding to the survey together. Pretest (pre) was administered at the beginning of the course and post-test (post) was administered at the end of the course in the introductory physics courses. The normalized gain, $g$, is listed for introductory courses for which both pre and postdata are available. Instructors' data are not shown here, as those data cannot be considered in a statistical manner. Four instructors self-reported that they performed near perfect, missing zero to two items.

\begin{tabular}{lccccccc}
\hline \hline & $\begin{array}{c}\text { Ph.D. student } \\
\text { Pairs }\end{array}$ & $\begin{array}{c}\text { Ph.D. } \\
\text { student Ind. }\end{array}$ & $\begin{array}{c}\text { Upper-under } \\
\text { Post }\end{array}$ & $\begin{array}{c}\text { Calculus- } \\
\text { based Pre }\end{array}$ & $\begin{array}{c}\text { Calculus- } \\
\text { based Post (g) }\end{array}$ & $\begin{array}{c}\text { Algebra- } \\
\text { based Pre }\end{array}$ & $\begin{array}{c}\text { Algebra-based } \\
\text { Post (g) }\end{array}$ \\
\cline { 2 - 7 }$N$ & 21 & 45 & 147 & 705 & 507 & 218 & 382 \\
\hline Total score (\%) & 75 & 55 & 57 & 29 & $37(0.11)$ & 30 & $37(0.10)$ \\
First law (\%) & 76 & 58 & 60 & 29 & $37(0.11)$ & 28 & $38(0.14)$ \\
Second law (\%) & 74 & 56 & 60 & 28 & $36(0.11)$ & 29 & $42(0.18)$ \\
$P V$ diagram (\%) & 71 & 53 & 56 & 28 & $38(0.14)$ & 29 & $29(0.0)$ \\
Reversible (\%) & 65 & 44 & 38 & 22 & $27(0.06)$ & 22 & $27(0.06)$ \\
Irreversible (\%) & 79 & 62 & 66 & 32 & $40(0.12)$ & 32 & $45(0.19)$ \\
\hline \hline
\end{tabular}

response to the first law question was that heat itself is conserved, with $15 \%$ of students making statements such as "There is no loss of total heat in the universe." These responses confirmed that many students in introductory physics have been exposed to the first and second laws of thermodynamics before instruction in the college physics course and the survey can be administered as a pretest before instruction in introductory courses.

\section{VALIDATION OF THE SURVEY INSTRUMENT}

While developing and validating the STPFaSL instrument, we paid particular attention to the issues of reliability and validity. Test reliability refers to the relative degree of consistency between the scores if an individual immediately repeats the test, and validity refers to the appropriateness of interpreting the test scores. We note that the STPFaSL instrument is appropriate for making interpretations about the effectiveness of instruction in relevant concepts in a particular course and it is not supposed to be used for high stakes testing of individual students. Also, although the survey instrument focuses on concepts that are typically covered in introductory thermodynamics and is appropriate for introductory students in physics courses, it was also validated and administered to undergraduates in upper-level thermodynamics and statistical mechanics courses in which these concepts are generally repeated and to first year physics Ph.D. students in order to obtain base line data and to ensure content validity (on average, advanced students should perform better than the introductory students for content validity).

Below, we describe the STPFaSL instrument in terms of the quantitative measures used in the classical test theory for a reliable survey instrument including item analysis (using item difficulty and point biserial coefficient) and
KR-20 [34,35]. We also discuss the content validity of the STPFaSL survey instrument using comparison with advanced student performance (the fact that the advanced students performed significantly better than introductory physics students on the instrument) and the stability of the introductory physics student responses when the order of distractors is switched in each item.

\section{A. Overall performance and item difficulty}

Table III shows the number of students in each group to whom the final version of the survey was administered, as well as the average performance of different groups on the entire survey instrument and on subsets of items focusing on particular themes. In this table, the average data from six institutions are presented because there was no statistically significant difference between the scores. In introductory courses, the pretest was administered before students learned about thermodynamics in that course and the post-test was administered after instruction in relevant concepts. The instructors generally administered pretests in their classes by awarding students bonus points as incentive to take the survey seriously but generally awarded students a small amount of quiz grade for taking it as a post-test. Moreover, since thermodynamics is covered after mechanics in the same course, some instructors teach it at the end of the first semester introductory physics course while others teach it at the beginning or in the middle of a second semester course. Furthermore, some instructors only spent two weeks on these topics whereas others spent up to four weeks in the introductory courses. However, we find that the scores in introductory courses were not statistically significantly different across the same type of course (algebra-based or calculus-based introductory physics course) taught by different instructors in different institutions regardless of the duration over 
which these topics were discussed. This may at least partly be due to the fact that students in the introductory physics courses in general performed very poorly on the posttest after traditional instruction (see Table III). Table III also lists Hake normalized gain $g$ defined as $g=$ $($ post $\%$-pre\%)/(100\%-pre\%) for introductory courses [13] for which both pretest and post-test data are available. The normalized gains show that introductory physics students did not improve much from pretest to post-test.

The item difficulty of each multiple-choice question on the instrument is simply the percent of students who correctly answered the question; i.e., it is the average score on a particular item. Results in the Table IV show not only the item difficulty of each question on the instrument but also the prevalence of different incorrect choices for each question for each group.

\section{B. Point biserial coefficient}

The point biserial coefficient (PBC), is designed to measure how well a given item predicts the overall score on a test. It is defined as the correlation coefficient between the score for a given item and the overall score. The PBC can take on values between -1 and 1 ; a negative value

TABLE IV. Average percentage scores for each of the five choices for each item on the STPFaSL instrument for each group. Pre or pretest refers to the data before instruction in a particular course in which the survey topics in thermodynamics were covered (as discussed in the text, students in a course may have learned these topics in other courses). Post or post-test refers to data after instruction in relevant concepts in that particular course. Abbreviations for various student groups: Upper (students in junior or senior level thermodynamics and physics Ph.D. students in their first semester of a Ph.D. program who had also only taken the junior or senior level thermodynamics course), Calc (students in introductory calculus-based physics courses), Algebra (students in introductory algebrabased physics courses). The first column shows the percentage of students who answer the item correctly, and the corresponding answer choice. The four remaining columns list the percentages of incorrect answers (and choices), ranked by frequency. The number of students in each group is the same as in Table III except upper-level post and Ph.D. students Ind. are combined into Upper Post.

\begin{tabular}{|c|c|c|c|c|c|c|}
\hline Problem No. & Correct $(\%)$ & $1 \mathrm{st}$ & 2nd & $3 \mathrm{rd}$ & 4 th & Level \\
\hline 1 & $\begin{array}{l}24(\mathrm{C}) \\
28(\mathrm{C}) \\
19(\mathrm{C}) \\
29(\mathrm{C}) \\
24(\mathrm{C})\end{array}$ & $\begin{array}{l}39(\mathrm{D}) \\
32(\mathrm{~A}) \\
51(\mathrm{~A}) \\
36(\mathrm{D}) \\
46(\mathrm{~A})\end{array}$ & $\begin{array}{l}28 \text { (A) } \\
29 \text { (D) } \\
16(\mathrm{D}) \\
29(\mathrm{~A}) \\
19 \text { (D) }\end{array}$ & $\begin{array}{r}5(\mathrm{E}) \\
8(\mathrm{~B}) \\
12(\mathrm{~B}) \\
4(\mathrm{~B}) \\
10(\mathrm{~B})\end{array}$ & $\begin{array}{l}4(B) \\
3(\mathrm{E}) \\
2(\mathrm{E}) \\
2(\mathrm{E}) \\
1(\mathrm{E})\end{array}$ & $\begin{array}{l}\text { Upper Post } \\
\text { Calc Post } \\
\text { Calc Pre } \\
\text { Algebra Post } \\
\text { Algebra Pre }\end{array}$ \\
\hline 2 & $\begin{array}{l}57(\mathrm{~A}) \\
35(\mathrm{~A}) \\
29(\mathrm{~A}) \\
39(\mathrm{~A}) \\
27(\mathrm{~A})\end{array}$ & $\begin{array}{l}14(\mathrm{C}) \\
24(\mathrm{C}) \\
33(\mathrm{C}) \\
20(\mathrm{C}) \\
38(\mathrm{C})\end{array}$ & $\begin{array}{l}10 \text { (D) } \\
16 \text { (D) } \\
14 \text { (B) } \\
15 \text { (D) } \\
13 \text { (D) }\end{array}$ & $\begin{array}{r}9(\mathrm{~B}) \\
13(\mathrm{E}) \\
14(\mathrm{D}) \\
14(\mathrm{E}) \\
12(\mathrm{E})\end{array}$ & $\begin{array}{r}9(\mathrm{E}) \\
11(\mathrm{~B}) \\
9(\mathrm{E}) \\
13(\mathrm{~B}) \\
10(\mathrm{~B})\end{array}$ & $\begin{array}{l}\text { Upper Post } \\
\text { Calc Post } \\
\text { Calc Pre } \\
\text { Algebra Post } \\
\text { Algebra Pre }\end{array}$ \\
\hline 3 & $\begin{array}{l}51(\mathrm{~B}) \\
28(\mathrm{~B}) \\
28(\mathrm{~B}) \\
29(\mathrm{~B}) \\
23(\mathrm{~B})\end{array}$ & $\begin{array}{l}23(\mathrm{~A}) \\
38(\mathrm{C}) \\
29(\mathrm{~A}) \\
33(\mathrm{C}) \\
29(\mathrm{D})\end{array}$ & $\begin{array}{l}18(\mathrm{C}) \\
22(\mathrm{~A}) \\
24(\mathrm{C}) \\
19(\mathrm{D}) \\
26(\mathrm{~A})\end{array}$ & $\begin{array}{r}8 \text { (D) } \\
11 \text { (D) } \\
19 \text { (D) } \\
18 \text { (A) } \\
21 \text { (C) }\end{array}$ & $\begin{array}{l}0(\mathrm{E}) \\
1(\mathrm{E}) \\
1(\mathrm{E}) \\
1(\mathrm{E}) \\
1(\mathrm{E})\end{array}$ & $\begin{array}{l}\text { Upper Post } \\
\text { Calc Post } \\
\text { Calc Pre } \\
\text { Algebra Post } \\
\text { Algebra Pre }\end{array}$ \\
\hline 4 & $\begin{array}{l}31(\mathrm{~B}) \\
28(\mathrm{~B}) \\
37(\mathrm{~B}) \\
32(\mathrm{~B}) \\
44(\mathrm{~B})\end{array}$ & $\begin{array}{l}42(\mathrm{C}) \\
36(\mathrm{C}) \\
25(\mathrm{C}) \\
43(\mathrm{C}) \\
20(\mathrm{C})\end{array}$ & $\begin{array}{l}23(\mathrm{~A}) \\
26(\mathrm{~A}) \\
23(\mathrm{~A}) \\
12(\mathrm{~A}) \\
19(\mathrm{~A})\end{array}$ & $\begin{array}{r}4 \text { (D) } \\
9 \text { (D) } \\
13 \text { (D) } \\
11 \text { (D) } \\
17 \text { (D) }\end{array}$ & $\begin{array}{l}0(\mathrm{E}) \\
1(\mathrm{E}) \\
1(\mathrm{E}) \\
1(\mathrm{E}) \\
0(\mathrm{E})\end{array}$ & $\begin{array}{l}\text { Upper Post } \\
\text { Calc Post } \\
\text { Calc Pre } \\
\text { Algebra Post } \\
\text { Algebra Pre }\end{array}$ \\
\hline 5 & $\begin{array}{l}74(\mathrm{~A}) \\
68(\mathrm{~A}) \\
61(\mathrm{~A}) \\
50(\mathrm{~A}) \\
63(\mathrm{~A})\end{array}$ & $\begin{array}{r}9(\mathrm{E}) \\
18(\mathrm{E}) \\
15(\mathrm{E}) \\
27(\mathrm{E}) \\
16(\mathrm{E})\end{array}$ & $\begin{array}{r}7 \text { (D) } \\
6 \text { (C) } \\
9 \text { (D) } \\
9 \text { (D) } \\
11 \text { (D) }\end{array}$ & $\begin{array}{l}6(\mathrm{C}) \\
4(\mathrm{D}) \\
9(\mathrm{~B}) \\
8(\mathrm{C}) \\
6(\mathrm{~B})\end{array}$ & $\begin{array}{l}4(\mathrm{~B}) \\
4(\mathrm{~B}) \\
7(\mathrm{C}) \\
5(\mathrm{~B}) \\
4(\mathrm{C})\end{array}$ & $\begin{array}{l}\text { Upper Post } \\
\text { Calc Post } \\
\text { Calc Pre } \\
\text { Algebra Post } \\
\text { Algebra Pre }\end{array}$ \\
\hline 6 & $\begin{array}{r}60(\mathrm{~B}) \\
27(\mathrm{~B}) \\
10(\mathrm{~B}) \\
9(\mathrm{~B}) \\
8(\mathrm{~B})\end{array}$ & $\begin{array}{l}23(\mathrm{~A}) \\
37(\mathrm{C}) \\
56(\mathrm{C}) \\
47(\mathrm{C}) \\
53(\mathrm{C})\end{array}$ & $\begin{array}{r}9(\mathrm{C}) \\
21(\mathrm{~A}) \\
18(\mathrm{~A}) \\
28(\mathrm{~A}) \\
20 \text { (A) }\end{array}$ & $\begin{array}{r}5(\mathrm{E}) \\
9(\mathrm{D}) \\
8(\mathrm{D}) \\
10 \text { (D) } \\
12 \text { (D) }\end{array}$ & $\begin{array}{l}3(\mathrm{D}) \\
5(\mathrm{E}) \\
8(\mathrm{E}) \\
6(\mathrm{E}) \\
8(\mathrm{E})\end{array}$ & $\begin{array}{l}\text { Upper Post } \\
\text { Calc Post } \\
\text { Calc Pre } \\
\text { Algebra Post } \\
\text { Algebra Pre }\end{array}$ \\
\hline
\end{tabular}


TABLE IV. (Continued)

\begin{tabular}{|c|c|c|c|c|c|c|}
\hline Problem No. & Correct $(\%)$ & $1 \mathrm{st}$ & 2nd & 3rd & 4th & Level \\
\hline 7 & $\begin{array}{l}41(\mathrm{C}) \\
53(\mathrm{C}) \\
55(\mathrm{C}) \\
43(\mathrm{C}) \\
62(\mathrm{C})\end{array}$ & $\begin{array}{l}36(\mathrm{~A}) \\
22(\mathrm{~A}) \\
17(\mathrm{~A}) \\
22(\mathrm{E}) \\
12(\mathrm{~A})\end{array}$ & $\begin{array}{l}9(\mathrm{E}) \\
13(\mathrm{E}) \\
10(\mathrm{E}) \\
21(\mathrm{~A}) \\
11(\mathrm{D})\end{array}$ & $\begin{array}{r}7(\mathrm{~B}) \\
6(\mathrm{~B}) \\
9(\mathrm{~B}) \\
7(\mathrm{~B}) \\
10(\mathrm{~B})\end{array}$ & $\begin{array}{l}7 \text { (D) } \\
6 \text { (D) } \\
8 \text { (D) } \\
7 \text { (D) } \\
5 \text { (E) }\end{array}$ & $\begin{array}{l}\text { Upper Post } \\
\text { Calc Post } \\
\text { Calc Pre } \\
\text { Algebra Post } \\
\text { Algebra Pre }\end{array}$ \\
\hline 8 & $\begin{array}{l}41(\mathrm{C}) \\
21(\mathrm{C}) \\
12(\mathrm{C}) \\
10(\mathrm{C}) \\
12(\mathrm{C})\end{array}$ & $\begin{array}{l}36(\mathrm{~B}) \\
33(\mathrm{~A}) \\
40(\mathrm{~A}) \\
37(\mathrm{~A}) \\
38(\mathrm{~A})\end{array}$ & $\begin{array}{l}11(\mathrm{~A}) \\
27(\mathrm{~B}) \\
25(\mathrm{~B}) \\
24(\mathrm{~B}) \\
21(\mathrm{~B})\end{array}$ & $\begin{array}{l}10 \text { (D) } \\
12 \text { (D) } \\
13 \text { (D) } \\
19 \text { (D) } \\
18 \text { (D) }\end{array}$ & $\begin{array}{r}3(\mathrm{E}) \\
7(\mathrm{E}) \\
9(\mathrm{E}) \\
10(\mathrm{E}) \\
12(\mathrm{E})\end{array}$ & $\begin{array}{l}\text { Upper Post } \\
\text { Calc Post } \\
\text { Calc Pre } \\
\text { Algebra Post } \\
\text { Algebra Pre }\end{array}$ \\
\hline 9 & $\begin{array}{l}56(\mathrm{E}) \\
40(\mathrm{E}) \\
26(\mathrm{E}) \\
38(\mathrm{E}) \\
32(\mathrm{E})\end{array}$ & $\begin{array}{l}18(\mathrm{~B}) \\
23(\mathrm{C}) \\
24(\mathrm{C}) \\
21(\mathrm{C}) \\
21(\mathrm{C})\end{array}$ & $\begin{array}{l}16(\mathrm{C}) \\
17(\mathrm{~B}) \\
19(\mathrm{D}) \\
17(\mathrm{~B}) \\
19 \text { (D) }\end{array}$ & $\begin{array}{l}7 \text { (A) } \\
11 \text { (D) } \\
19 \text { (B) } \\
15 \text { (D) } \\
15 \text { (B) }\end{array}$ & $\begin{array}{r}3(\mathrm{D}) \\
9(\mathrm{~A}) \\
12(\mathrm{~A}) \\
10(\mathrm{~A}) \\
13(\mathrm{~A})\end{array}$ & $\begin{array}{l}\text { Upper Post } \\
\text { Calc Post } \\
\text { Calc Pre } \\
\text { Algebra Post } \\
\text { Algebra Pre }\end{array}$ \\
\hline 10 & $\begin{array}{l}53(\mathrm{E}) \\
23(\mathrm{E}) \\
15(\mathrm{E}) \\
23(\mathrm{E}) \\
17(\mathrm{E})\end{array}$ & $\begin{array}{l}19(\mathrm{D}) \\
30(\mathrm{~B}) \\
40(\mathrm{~B}) \\
36(\mathrm{~B}) \\
41(\mathrm{~B})\end{array}$ & $\begin{array}{l}11(\mathrm{~B}) \\
23(\mathrm{~A}) \\
27(\mathrm{~A}) \\
27(\mathrm{~A}) \\
28(\mathrm{~A})\end{array}$ & $\begin{array}{r}11(\mathrm{~A}) \\
14(\mathrm{D}) \\
9(\mathrm{C}) \\
8(\mathrm{D}) \\
11(\mathrm{C})\end{array}$ & $\begin{array}{r}6(\mathrm{C}) \\
10(\mathrm{C}) \\
9(\mathrm{D}) \\
6(\mathrm{C}) \\
3(\mathrm{D})\end{array}$ & $\begin{array}{l}\text { Upper Post } \\
\text { Calc Post } \\
\text { Calc Pre } \\
\text { Algebra Post } \\
\text { Algebra Pre }\end{array}$ \\
\hline 11 & $\begin{array}{l}80(\mathrm{C}) \\
69(\mathrm{C}) \\
57(\mathrm{C}) \\
65(\mathrm{C}) \\
50(\mathrm{C})\end{array}$ & $\begin{array}{r}9(\mathrm{~A}) \\
14(\mathrm{~A}) \\
17(\mathrm{~A}) \\
19(\mathrm{~A}) \\
26(\mathrm{~A})\end{array}$ & $\begin{array}{r}4(\mathrm{E}) \\
8(\mathrm{~B}) \\
11(\mathrm{~B}) \\
10(\mathrm{~B}) \\
11(\mathrm{D})\end{array}$ & $\begin{array}{r}4 \text { (D) } \\
6 \text { (D) } \\
11 \text { (D) } \\
3 \text { (D) } \\
9 \text { (B) }\end{array}$ & $\begin{array}{l}3(\mathrm{~B}) \\
2(\mathrm{E}) \\
4(\mathrm{E}) \\
2(\mathrm{E}) \\
4(\mathrm{E})\end{array}$ & $\begin{array}{l}\text { Upper Post } \\
\text { Calc Post } \\
\text { Calc Pre } \\
\text { Algebra Post } \\
\text { Algebra Pre }\end{array}$ \\
\hline 12 & $\begin{array}{l}62 \text { (D) } \\
31 \text { (D) } \\
24 \text { (D) } \\
32 \text { (D) } \\
29 \text { (D) }\end{array}$ & $\begin{array}{l}17 \text { (A) } \\
40(\mathrm{~A}) \\
44(\mathrm{~A}) \\
41(\mathrm{~A}) \\
39(\mathrm{~A})\end{array}$ & $\begin{array}{l}13(\mathrm{E}) \\
15(\mathrm{E}) \\
13(\mathrm{E}) \\
12(\mathrm{C}) \\
17(\mathrm{E})\end{array}$ & $\begin{array}{r}6(\mathrm{C}) \\
10(\mathrm{C}) \\
13(\mathrm{C}) \\
12(\mathrm{E}) \\
11(\mathrm{C})\end{array}$ & $\begin{array}{l}2(\mathrm{~B}) \\
5(\mathrm{~B}) \\
6(\mathrm{~B}) \\
3(\mathrm{~B}) \\
4(\mathrm{~B})\end{array}$ & $\begin{array}{l}\text { Upper Post } \\
\text { Calc Post } \\
\text { Calc Pre } \\
\text { Algebra Post } \\
\text { Algebra Pre }\end{array}$ \\
\hline 13 & $\begin{array}{l}74(\mathrm{C}) \\
43(\mathrm{C}) \\
36(\mathrm{C}) \\
61(\mathrm{C}) \\
43(\mathrm{C})\end{array}$ & $\begin{array}{l}14(\mathrm{E}) \\
24(\mathrm{E}) \\
30(\mathrm{E}) \\
18(\mathrm{~B}) \\
24(\mathrm{~B})\end{array}$ & $\begin{array}{r}9(\mathrm{~B}) \\
24(\mathrm{~B}) \\
23(\mathrm{~B}) \\
14(\mathrm{E}) \\
19(\mathrm{E})\end{array}$ & $\begin{array}{r}3(\mathrm{~A}) \\
5(\mathrm{D}) \\
7(\mathrm{D}) \\
4(\mathrm{~A}) \\
10(\mathrm{D})\end{array}$ & $\begin{array}{l}0(\mathrm{D}) \\
4(\mathrm{~A}) \\
5(\mathrm{~A}) \\
3(\mathrm{D}) \\
4(\mathrm{~A})\end{array}$ & $\begin{array}{l}\text { Upper Post } \\
\text { Calc Post } \\
\text { Calc Pre } \\
\text { Algebra Post } \\
\text { Algebra Pre }\end{array}$ \\
\hline 14 & $\begin{array}{l}55(\mathrm{E}) \\
30(\mathrm{E}) \\
21(\mathrm{E}) \\
28(\mathrm{E}) \\
20(\mathrm{E})\end{array}$ & $\begin{array}{l}18(\mathrm{C}) \\
32(\mathrm{C}) \\
28(\mathrm{C}) \\
31(\mathrm{C}) \\
28(\mathrm{D})\end{array}$ & $\begin{array}{l}16 \text { (D) } \\
17 \text { (A) } \\
20 \text { (D) } \\
19 \text { (D) } \\
24 \text { (C) }\end{array}$ & $\begin{array}{r}8(\mathrm{~A}) \\
15(\mathrm{D}) \\
17(\mathrm{~A}) \\
19(\mathrm{~A}) \\
16(\mathrm{~A})\end{array}$ & $\begin{array}{r}3(\mathrm{~B}) \\
6(\mathrm{~B}) \\
14(\mathrm{~B}) \\
3(\mathrm{~B}) \\
12(\mathrm{~B})\end{array}$ & $\begin{array}{l}\text { Upper Post } \\
\text { Calc Post } \\
\text { Calc Pre } \\
\text { Algebra Post } \\
\text { Algebra Pre }\end{array}$ \\
\hline 15 & $\begin{array}{r}40(\mathrm{E}) \\
22(\mathrm{E}) \\
11(\mathrm{E}) \\
11(\mathrm{E}) \\
9(\mathrm{E})\end{array}$ & $\begin{array}{l}29 \text { (D) } \\
43(\mathrm{~A}) \\
43(\mathrm{~A}) \\
50(\mathrm{~A}) \\
53(\mathrm{~A})\end{array}$ & $\begin{array}{l}22 \text { (A) } \\
17 \text { (D) } \\
18 \text { (C) } \\
14 \text { (D) } \\
15 \text { (D) }\end{array}$ & $\begin{array}{r}6(\mathrm{C}) \\
11(\mathrm{C}) \\
14(\mathrm{D}) \\
13(\mathrm{~B}) \\
12(\mathrm{C})\end{array}$ & $\begin{array}{r}4(\mathrm{~B}) \\
8(\mathrm{~B}) \\
13(\mathrm{~B}) \\
12(\mathrm{C}) \\
11(\mathrm{~B})\end{array}$ & $\begin{array}{l}\text { Upper Post } \\
\text { Calc Post } \\
\text { Calc Pre } \\
\text { Algebra Post } \\
\text { Algebra Pre }\end{array}$ \\
\hline 16 & $\begin{array}{l}58 \text { (D) } \\
27 \text { (D) } \\
19 \text { (D) } \\
27 \text { (D) } \\
16 \text { (D) }\end{array}$ & $\begin{array}{l}22(\mathrm{E}) \\
27(\mathrm{C}) \\
33(\mathrm{C}) \\
40(\mathrm{E}) \\
36(\mathrm{C})\end{array}$ & $\begin{array}{l}15(\mathrm{C}) \\
27(\mathrm{E}) \\
21(\mathrm{E}) \\
19(\mathrm{C}) \\
24(\mathrm{E})\end{array}$ & $\begin{array}{r}4(\mathrm{~B}) \\
14(\mathrm{~B}) \\
17(\mathrm{~B}) \\
9(\mathrm{~B}) \\
12(\mathrm{~B})\end{array}$ & $\begin{aligned} 1 & (\mathrm{~A}) \\
5 & (\mathrm{~A}) \\
10 & (\mathrm{~A}) \\
5 & (\mathrm{~A}) \\
11 & (\mathrm{~A})\end{aligned}$ & $\begin{array}{l}\text { Upper Post } \\
\text { Calc Post } \\
\text { Calc Pre } \\
\text { Algebra Post } \\
\text { Algebra Pre }\end{array}$ \\
\hline
\end{tabular}


TABLE IV. (Continued)

\begin{tabular}{|c|c|c|c|c|c|c|}
\hline Problem No. & Correct $(\%)$ & $1 \mathrm{st}$ & 2nd & $3 r d$ & 4 th & Level \\
\hline 17 & $\begin{array}{l}72(\mathrm{E}) \\
58(\mathrm{E}) \\
50(\mathrm{E}) \\
48(\mathrm{E}) \\
55(\mathrm{E})\end{array}$ & $\begin{array}{l}14(\mathrm{C}) \\
19(\mathrm{C}) \\
19(\mathrm{C}) \\
21(\mathrm{C}) \\
20(\mathrm{C})\end{array}$ & $\begin{array}{r}7(\mathrm{~B}) \\
10(\mathrm{~A}) \\
12(\mathrm{~B}) \\
14(\mathrm{~A}) \\
9 \text { (A) }\end{array}$ & $\begin{array}{r}4(\mathrm{~A}) \\
8(\mathrm{~B}) \\
11(\mathrm{~A}) \\
10(\mathrm{~B}) \\
9(\mathrm{~B})\end{array}$ & $\begin{array}{l}3 \text { (D) } \\
5 \text { (D) } \\
9 \text { (D) } \\
7 \text { (D) } \\
7 \text { (D) }\end{array}$ & $\begin{array}{l}\text { Upper Post } \\
\text { Calc Post } \\
\text { Calc Pre } \\
\text { Algebra Post } \\
\text { Algebra Pre }\end{array}$ \\
\hline 18 & $\begin{array}{l}75(\mathrm{~B}) \\
37(\mathrm{~B}) \\
20(\mathrm{~B}) \\
46(\mathrm{~B}) \\
37(\mathrm{~B})\end{array}$ & $\begin{array}{r}9(\mathrm{C}) \\
28(\mathrm{C}) \\
34(\mathrm{C}) \\
21(\mathrm{E}) \\
23(\mathrm{C})\end{array}$ & $\begin{array}{l}6(\mathrm{D}) \\
16(\mathrm{E}) \\
16(\mathrm{E}) \\
18(\mathrm{C}) \\
15(\mathrm{D})\end{array}$ & $\begin{array}{r}6(\mathrm{E}) \\
11(\mathrm{D}) \\
15(\mathrm{~A}) \\
9(\mathrm{D}) \\
14(\mathrm{E})\end{array}$ & $\begin{array}{r}3(\mathrm{~A}) \\
8(\mathrm{~A}) \\
15(\mathrm{D}) \\
6(\mathrm{~A}) \\
12(\mathrm{~A})\end{array}$ & $\begin{array}{l}\text { Upper Post } \\
\text { Calc Post } \\
\text { Calc Pre } \\
\text { Algebra Post } \\
\text { Algebra Pre }\end{array}$ \\
\hline 19 & $\begin{array}{l}28(\mathrm{E}) \\
25(\mathrm{E}) \\
18(\mathrm{E}) \\
37(\mathrm{E}) \\
21(\mathrm{E})\end{array}$ & $\begin{array}{l}34(\mathrm{~B}) \\
24(\mathrm{~B}) \\
26(\mathrm{~B}) \\
25(\mathrm{D}) \\
27 \text { (D) }\end{array}$ & $\begin{array}{l}19(\mathrm{C}) \\
19(\mathrm{C}) \\
20(\mathrm{D}) \\
18(\mathrm{~B}) \\
22(\mathrm{~B})\end{array}$ & $\begin{array}{l}16(\mathrm{D}) \\
17(\mathrm{D}) \\
19(\mathrm{C}) \\
10(\mathrm{~A}) \\
18(\mathrm{C})\end{array}$ & $\begin{array}{l}4(\mathrm{~A}) \\
15(\mathrm{~A}) \\
17(\mathrm{~A}) \\
10(\mathrm{C}) \\
11(\mathrm{~A})\end{array}$ & $\begin{array}{l}\text { Upper Post } \\
\text { Calc Post } \\
\text { Calc Pre } \\
\text { Algebra Post } \\
\text { Algebra Pre }\end{array}$ \\
\hline 20 & $\begin{array}{l}51(\mathrm{~A}) \\
31(\mathrm{~A}) \\
23(\mathrm{~A}) \\
44(\mathrm{~A}) \\
23(\mathrm{~A})\end{array}$ & $\begin{array}{l}20(\mathrm{C}) \\
30(\mathrm{C}) \\
26(\mathrm{C}) \\
22(\mathrm{C}) \\
24(\mathrm{C})\end{array}$ & $\begin{array}{l}16 \text { (D) } \\
16 \text { (D) } \\
22 \text { (D) } \\
14 \text { (B) } \\
20 \text { (B) }\end{array}$ & $\begin{array}{l}10(\mathrm{~B}) \\
14(\mathrm{~B}) \\
17 \text { (B) } \\
11 \text { (D) } \\
18 \text { (D) }\end{array}$ & $\begin{array}{r}3(\mathrm{E}) \\
9(\mathrm{E}) \\
12(\mathrm{E}) \\
9(\mathrm{E}) \\
16(\mathrm{E})\end{array}$ & $\begin{array}{l}\text { Upper Post } \\
\text { Calc Post } \\
\text { Calc Pre } \\
\text { Algebra Post } \\
\text { Algebra Pre }\end{array}$ \\
\hline 21 & $\begin{array}{l}70(\mathrm{~B}) \\
49(\mathrm{~B}) \\
35(\mathrm{~B}) \\
44(\mathrm{~B}) \\
37(\mathrm{~B})\end{array}$ & $\begin{array}{l}12(\mathrm{E}) \\
16(\mathrm{D}) \\
20(\mathrm{C}) \\
21(\mathrm{E}) \\
19(\mathrm{D})\end{array}$ & $\begin{array}{l}10(\mathrm{D}) \\
16(\mathrm{E}) \\
19(\mathrm{D}) \\
15(\mathrm{D}) \\
18(\mathrm{C})\end{array}$ & $\begin{array}{r}5(\mathrm{C}) \\
9(\mathrm{~A}) \\
13(\mathrm{~A}) \\
12(\mathrm{C}) \\
16(\mathrm{E})\end{array}$ & $\begin{array}{r}2(\mathrm{~A}) \\
9(\mathrm{C}) \\
13(\mathrm{E}) \\
9(\mathrm{~A}) \\
10(\mathrm{~A})\end{array}$ & $\begin{array}{l}\text { Upper Post } \\
\text { Calc Post } \\
\text { Calc Pre } \\
\text { Algebra Post } \\
\text { Algebra Pre }\end{array}$ \\
\hline 22 & $\begin{array}{l}78 \text { (D) } \\
52 \text { (D) } \\
44 \text { (D) } \\
49 \text { (D) } \\
51 \text { (D) }\end{array}$ & $\begin{array}{l}16(\mathrm{~B}) \\
16(\mathrm{~B}) \\
19(\mathrm{E}) \\
16(\mathrm{~B}) \\
18(\mathrm{E})\end{array}$ & $\begin{array}{l}4(\mathrm{C}) \\
12(\mathrm{E}) \\
17(\mathrm{~B}) \\
13(\mathrm{C}) \\
16(\mathrm{~B})\end{array}$ & $\begin{array}{l}3(\mathrm{~A}) \\
12(\mathrm{C}) \\
12(\mathrm{C}) \\
11(\mathrm{~A}) \\
10(\mathrm{C})\end{array}$ & $\begin{array}{r}0(\mathrm{E}) \\
7(\mathrm{~A}) \\
8(\mathrm{~A}) \\
11(\mathrm{E}) \\
6(\mathrm{~A})\end{array}$ & $\begin{array}{l}\text { Upper Post } \\
\text { Calc Post } \\
\text { Calc Pre } \\
\text { Algebra Post } \\
\text { Algebra Pre }\end{array}$ \\
\hline 23 & $\begin{array}{l}62(\mathrm{~A}) \\
52(\mathrm{~A}) \\
43(\mathrm{~A}) \\
46(\mathrm{~A}) \\
40(\mathrm{~A})\end{array}$ & $\begin{array}{l}22(\mathrm{C}) \\
20(\mathrm{C}) \\
21(\mathrm{C}) \\
20(\mathrm{C}) \\
25(\mathrm{~B})\end{array}$ & $\begin{array}{l}9 \text { (D) } \\
14 \text { (D) } \\
18 \text { (B) } \\
18 \text { (D) } \\
20 \text { (C) }\end{array}$ & $\begin{array}{l}5 \text { (B) } \\
11 \text { (B) } \\
12 \text { (D) } \\
14 \text { (B) } \\
11 \text { (D) }\end{array}$ & $\begin{array}{l}2(\mathrm{E}) \\
2(\mathrm{E}) \\
5(\mathrm{E}) \\
1(\mathrm{E}) \\
3(\mathrm{E})\end{array}$ & $\begin{array}{l}\text { Upper Post } \\
\text { Calc Post } \\
\text { Calc Pre } \\
\text { Algebra Post } \\
\text { Algebra Pre }\end{array}$ \\
\hline 24 & $\begin{array}{l}64 \text { (D) } \\
32 \text { (D) } \\
24 \text { (D) } \\
31 \text { (D) } \\
30 \text { (D) }\end{array}$ & $\begin{array}{l}15(\mathrm{~A}) \\
42(\mathrm{~A}) \\
39(\mathrm{~A}) \\
41(\mathrm{~A}) \\
43(\mathrm{~A})\end{array}$ & $\begin{array}{l}14(\mathrm{E}) \\
12(\mathrm{E}) \\
13(\mathrm{C}) \\
11(\mathrm{E}) \\
11(\mathrm{C})\end{array}$ & $\begin{array}{r}5(\mathrm{C}) \\
9(\mathrm{C}) \\
12(\mathrm{E}) \\
9(\mathrm{C}) \\
9(\mathrm{~B})\end{array}$ & $\begin{array}{r}2(\mathrm{~B}) \\
6(\mathrm{~B}) \\
11(\mathrm{~B}) \\
8(\mathrm{~B}) \\
7(\mathrm{E})\end{array}$ & $\begin{array}{l}\text { Upper Post } \\
\text { Calc Post } \\
\text { Calc Pre } \\
\text { Algebra Post } \\
\text { Algebra Pre }\end{array}$ \\
\hline 25 & $\begin{array}{l}69(\mathrm{C}) \\
38(\mathrm{C}) \\
29(\mathrm{C}) \\
57(\mathrm{C}) \\
35(\mathrm{C})\end{array}$ & $\begin{array}{l}20(\mathrm{E}) \\
26(\mathrm{~B}) \\
28(\mathrm{~B}) \\
18(\mathrm{E}) \\
21(\mathrm{~B})\end{array}$ & $\begin{aligned} & 9(\mathrm{~B}) \\
& 23(\mathrm{E}) \\
& 25(\mathrm{E}) \\
& 17(\mathrm{~B}) \\
& 21(\mathrm{E})\end{aligned}$ & $\begin{array}{r}2 \text { (D) } \\
7 \text { (D) } \\
12 \text { (D) } \\
5 \text { (D) } \\
15 \text { (D) }\end{array}$ & $\begin{array}{l}0(\mathrm{~A}) \\
6(\mathrm{~A}) \\
5(\mathrm{~A}) \\
3(\mathrm{~A}) \\
8(\mathrm{~A})\end{array}$ & $\begin{array}{l}\text { Upper Post } \\
\text { Calc Post } \\
\text { Calc Pre } \\
\text { Algebra Post } \\
\text { Algebra Pre }\end{array}$ \\
\hline 26 & $\begin{array}{l}65(\mathrm{E}) \\
41(\mathrm{E}) \\
17(\mathrm{E}) \\
31(\mathrm{E}) \\
17(\mathrm{E})\end{array}$ & $\begin{array}{l}12 \text { (D) } \\
19 \text { (B) } \\
25(\mathrm{~B}) \\
26(\mathrm{~B}) \\
27 \text { (D) }\end{array}$ & $\begin{array}{l}11(\mathrm{~B}) \\
18(\mathrm{C}) \\
23(\mathrm{D}) \\
20(\mathrm{D}) \\
27(\mathrm{~B})\end{array}$ & $\begin{array}{l}10(\mathrm{C}) \\
15(\mathrm{D}) \\
22(\mathrm{C}) \\
14(\mathrm{C}) \\
18(\mathrm{C})\end{array}$ & $\begin{array}{r}2(\mathrm{~A}) \\
7(\mathrm{~A}) \\
13(\mathrm{~A}) \\
9(\mathrm{~A}) \\
11(\mathrm{~A})\end{array}$ & $\begin{array}{l}\text { Upper Post } \\
\text { Calc Post } \\
\text { Calc Pre } \\
\text { Algebra Post } \\
\text { Algebra Pre }\end{array}$ \\
\hline
\end{tabular}


TABLE IV. (Continued)

\begin{tabular}{|c|c|c|c|c|c|c|}
\hline Problem No. & Correct $(\%)$ & $1 \mathrm{st}$ & $2 \mathrm{nd}$ & 3rd & 4th & Level \\
\hline 27 & $\begin{array}{l}74 \text { (D) } \\
34 \text { (D) } \\
25 \text { (D) } \\
35 \text { (D) } \\
28 \text { (D) }\end{array}$ & $\begin{array}{l}10(\mathrm{C}) \\
31(\mathrm{C}) \\
27(\mathrm{C}) \\
29(\mathrm{C}) \\
25(\mathrm{C})\end{array}$ & $\begin{array}{r}6(\mathrm{E}) \\
13(\mathrm{E}) \\
21(\mathrm{~B}) \\
16(\mathrm{~B}) \\
25(\mathrm{~B})\end{array}$ & $\begin{array}{r}6(\mathrm{~B}) \\
11(\mathrm{~B}) \\
15(\mathrm{E}) \\
11(\mathrm{E}) \\
14(\mathrm{~A})\end{array}$ & $\begin{array}{r}4(\mathrm{~A}) \\
10(\mathrm{~A}) \\
11(\mathrm{~A}) \\
9(\mathrm{~A}) \\
8(\mathrm{E})\end{array}$ & $\begin{array}{l}\text { Upper Post } \\
\text { Calc Post } \\
\text { Calc Pre } \\
\text { Algebra Post } \\
\text { Algebra Pre }\end{array}$ \\
\hline 28 & $\begin{array}{r}14(\mathrm{E}) \\
14(\mathrm{E}) \\
11(\mathrm{E}) \\
14(\mathrm{E}) \\
9(\mathrm{E})\end{array}$ & $\begin{array}{l}26(\mathrm{C}) \\
27(\mathrm{D}) \\
25(\mathrm{~B}) \\
30(\mathrm{D}) \\
33(\mathrm{D})\end{array}$ & $\begin{array}{l}26 \text { (D) } \\
27 \text { (B) } \\
23 \text { (D) } \\
28(\mathrm{~B}) \\
23(\mathrm{~A})\end{array}$ & $\begin{array}{l}20(\mathrm{~B}) \\
17(\mathrm{C}) \\
22(\mathrm{~A}) \\
14(\mathrm{~A}) \\
18(\mathrm{~B})\end{array}$ & $\begin{array}{l}14(\mathrm{~A}) \\
16(\mathrm{~A}) \\
18(\mathrm{C}) \\
14(\mathrm{C}) \\
18(\mathrm{C})\end{array}$ & $\begin{array}{l}\text { Upper Post } \\
\text { Calc Post } \\
\text { Calc Pre } \\
\text { Algebra Post } \\
\text { Algebra Pre }\end{array}$ \\
\hline 29 & $\begin{array}{l}68(\mathrm{~A}) \\
43(\mathrm{~A}) \\
35(\mathrm{~A}) \\
57(\mathrm{~A}) \\
40(\mathrm{~A})\end{array}$ & $\begin{array}{l}15(\mathrm{~B}) \\
24(\mathrm{~B}) \\
23(\mathrm{~B}) \\
16(\mathrm{~B}) \\
21(\mathrm{~B})\end{array}$ & $\begin{array}{r}9 \text { (D) } \\
17(\mathrm{C}) \\
20(\mathrm{C}) \\
13(\mathrm{C}) \\
17 \text { (D) }\end{array}$ & $\begin{array}{r}7(\mathrm{C}) \\
8 \text { (D) } \\
15 \text { (D) } \\
10(\mathrm{D}) \\
15 \text { (C) }\end{array}$ & $\begin{array}{l}1(\mathrm{E}) \\
7(\mathrm{E}) \\
7(\mathrm{E}) \\
4(\mathrm{E}) \\
7(\mathrm{E})\end{array}$ & $\begin{array}{l}\text { Upper Post } \\
\text { Calc Post } \\
\text { Calc Pre } \\
\text { Algebra Post } \\
\text { Algebra Pre }\end{array}$ \\
\hline 30 & $\begin{array}{l}37 \text { (D) } \\
19 \text { (D) } \\
17 \text { (D) } \\
14 \text { (D) } \\
11 \text { (D) }\end{array}$ & $\begin{array}{l}24(\mathrm{~A}) \\
36(\mathrm{C}) \\
33(\mathrm{C}) \\
47(\mathrm{C}) \\
42(\mathrm{C})\end{array}$ & $\begin{array}{l}22(\mathrm{C}) \\
23(\mathrm{~B}) \\
25(\mathrm{~B}) \\
22(\mathrm{~B}) \\
21(\mathrm{~A})\end{array}$ & $\begin{array}{r}11(\mathrm{~B}) \\
19(\mathrm{~A}) \\
18(\mathrm{~A}) \\
9(\mathrm{~A}) \\
18(\mathrm{~B})\end{array}$ & $\begin{array}{l}5(\mathrm{E}) \\
4(\mathrm{E}) \\
8(\mathrm{E}) \\
8(\mathrm{E}) \\
8(\mathrm{E})\end{array}$ & $\begin{array}{l}\text { Upper Post } \\
\text { Calc Post } \\
\text { Calc Pre } \\
\text { Algebra Post } \\
\text { Algebra Pre }\end{array}$ \\
\hline 31 & $\begin{array}{l}57(\mathrm{~A}) \\
42(\mathrm{~A}) \\
36(\mathrm{~A}) \\
46(\mathrm{~A}) \\
35(\mathrm{~A})\end{array}$ & $\begin{array}{l}24(\mathrm{C}) \\
20(\mathrm{~B}) \\
21(\mathrm{C}) \\
21(\mathrm{D}) \\
25(\mathrm{~B})\end{array}$ & $\begin{array}{l}11(\mathrm{~B}) \\
18(\mathrm{C}) \\
20(\mathrm{~B}) \\
16(\mathrm{C}) \\
21(\mathrm{D})\end{array}$ & $\begin{array}{l}6 \text { (D) } \\
16(\mathrm{D}) \\
17(\mathrm{D}) \\
14(\mathrm{~B}) \\
16 \text { (C) }\end{array}$ & $\begin{array}{l}2(\mathrm{E}) \\
4(\mathrm{E}) \\
5(\mathrm{E}) \\
2(\mathrm{E}) \\
3(\mathrm{E})\end{array}$ & $\begin{array}{l}\text { Upper Post } \\
\text { Calc Post } \\
\text { Calc Pre } \\
\text { Algebra Post } \\
\text { Algebra Pre }\end{array}$ \\
\hline 32 & $\begin{array}{l}62(\mathrm{C}) \\
37(\mathrm{C}) \\
33(\mathrm{C}) \\
40(\mathrm{C}) \\
27(\mathrm{C})\end{array}$ & $\begin{array}{l}21(\mathrm{~A}) \\
23(\mathrm{~A}) \\
23(\mathrm{D}) \\
22(\mathrm{~A}) \\
31(\mathrm{~A})\end{array}$ & $\begin{array}{r}8 \text { (D) } \\
21 \text { (D) } \\
21 \text { (A) } \\
18 \text { (D) } \\
16 \text { (D) }\end{array}$ & $\begin{array}{r}6 \text { (B) } \\
13(\mathrm{~B}) \\
15(\mathrm{~B}) \\
15(\mathrm{~B}) \\
13 \text { (B) }\end{array}$ & $\begin{array}{r}3(\mathrm{E}) \\
7(\mathrm{E}) \\
8(\mathrm{E}) \\
5(\mathrm{E}) \\
12(\mathrm{E})\end{array}$ & $\begin{array}{l}\text { Upper Post } \\
\text { Calc Post } \\
\text { Calc Pre } \\
\text { Algebra Post } \\
\text { Algebra Pre }\end{array}$ \\
\hline 33 & $\begin{array}{l}75(\mathrm{C}) \\
43(\mathrm{C}) \\
32(\mathrm{C}) \\
49(\mathrm{C}) \\
25(\mathrm{C})\end{array}$ & $\begin{array}{l}12(\mathrm{E}) \\
22(\mathrm{~B}) \\
24(\mathrm{~B}) \\
18(\mathrm{E}) \\
23(\mathrm{~A})\end{array}$ & $\begin{array}{l}6(B) \\
19(\mathrm{E}) \\
20(\mathrm{E}) \\
15(\mathrm{~B}) \\
19(\mathrm{~B})\end{array}$ & $\begin{array}{r}4(\mathrm{D}) \\
9(\mathrm{D}) \\
13(\mathrm{~A}) \\
12(\mathrm{D}) \\
18(\mathrm{E})\end{array}$ & $\begin{array}{r}2(\mathrm{~A}) \\
7(\mathrm{~A}) \\
10(\mathrm{D}) \\
6(\mathrm{~A}) \\
16(\mathrm{D})\end{array}$ & $\begin{array}{l}\text { Upper Post } \\
\text { Calc Post } \\
\text { Calc Pre } \\
\text { Algebra Post } \\
\text { Algebra Pre }\end{array}$ \\
\hline
\end{tabular}

indicates that otherwise high-performing students score poorly on this item, and otherwise poorly performing students do well on the item. The point biserial coefficients are shown in Fig. 2. A widely used criterion [35] is that it is desirable for this measure to be greater than or equal to 0.2 , which is exceeded for 32 of the 33 items on the STPFaSL. The first item, which was considered to be a valuable item by experts (and hence is kept), has low PBC due to the fact that even those students who perform well overall have difficulty distinguishing whether the change in the entropy of a system in a reversible adiabatic process is zero because the reversible process is adiabatic or whether the change in entropy of the system is zero in reversible processes in general (partly due to confusion between the system and the Universe).

\section{Reliability}

One way to measure reliability of the test instrument is to prepare an ensemble of identical students, administer the test instrument to them, and analyze the resulting distribution of item and overall scores. Since this is generally impractical, instead, a method is devised to use subsets of the test itself, and consider the correlation between different subsets. The Kuder-Richardson reliability index (KR-20) [34-36], which is a measure of the self-consistency of the entire test instrument, can take a value between 0 and 1 (it divides the full instrument into subsets and the consistency between the scores on different subsets is estimated). If guessing is high, KR-20 will be low. The KR-20 for introductory calculus-based and algebra-based courses was 0.77 and 0.61 , respectively, after instruction and for 


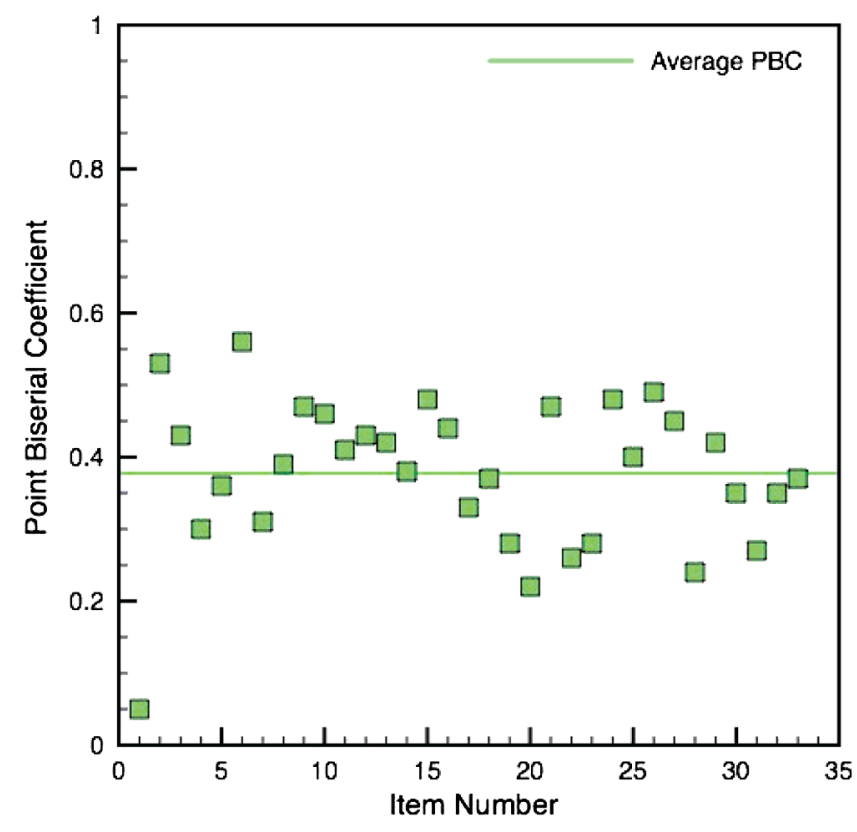

FIG. 2. PBC for each item. The solid line represents the mean value for all items.

graduate students and upper-level undergraduates used to benchmark the survey was 0.87 and 0.79 , respectively. These values are reasonable for predictions about a group of students and the higher values for students with more robust knowledge are expected due to lower guessing [34-36].

\section{Content validity via administration to students groups at different levels}

The survey instrument administration to upper-level students and Ph.D. students is useful for content validity. The content validity refers to the fact that the performance of students on the survey instrument closely corresponds to the model of expected performance. One measure of content validity can come from the expectation that introductory students will be outperformed by upper-level undergraduates and Ph.D. students and pairs of Ph.D. students working together will outperform those working individually. More than a thousand students from introductory courses in which these concepts have been covered have been administered the final version of the survey instrument and upper level undergraduates in thermodynamic and statistical mechanics courses have participated for the purposes of benchmarking and content validity of the instrument (see Table III). In addition, 45 entering physics Ph.D. students in their first semester of the Ph.D. program (who had not yet taken Ph.D. level thermodynamics) were administered the survey instrument individually and in pairs (after working on it individually).

The mean performance across the 33 items and the number of students who participated in the survey at each level are shown in Table III. "Upper-under" consists of advanced undergraduates and "Ph.D. students Ind." refers to entering Ph.D. students in their first semester of the Ph.D. program taking the survey individually. Ph.D. student pairs consist of small groups (most in pairs and one group with 3) of Ph.D. students discussing and responding to the survey together. Moreover, four faculty members who teach thermodynamics regularly and took the survey self-reported that they performed nearly perfectly, missing zero to two items. Thus, as one considers levels from advanced to introductory, performance deteriorates. From pairs of Ph.D. students to pretest scores for introductory students, the average performance drops from $75 \%$ to $29 \%$. The average data for each group tabulated in Table III and the expected trends observed serve as a measure of content validity.

\section{E. Effect of ordering distractors on student performance}

We performed an investigation to evaluate a different form of reliability and validity of the STPFaSL instrument. In particular, the answer choices were reordered to determine if answer choice ordering had an effect on student performance. One version was the original order, and three more versions differing only in answer choice order were administered to students in a calculus-based introductory physics course after instruction in relevant concepts. Students were randomly assigned one of these versions. Performing a Kruskal-Wallis test for statistically significant difference between any of the four sets found no difference. In particular, the $p$ value that differences between the four groups were due to chance alone was found to be 0.994 [35]. This study was performed with a total of 226 students who scored an average of $36.9 \%$, which was typical of the average performance of students in a calculus-based introductory course after instruction from different universities (post-test) (see Table III).

\section{F. A glance to student difficulties on the validated survey}

Details about student difficulties found using the STPFaSL instrument and comparison with prior studies are beyond the scope of this paper and will be presented elsewhere. However, we note that since the STPFaSL instrument has been administered to a large number of students at six different institutions, quantitative conclusions can be drawn about the prevalence of the many conceptual difficulties students have with these fundamental concepts in thermodynamics (see Table IV for average performance of each group on each question). Moreover, Figs. 3 and 4 depict the average percentage scores for students in the algebra-based and calculusbased introductory physics courses, respectively, on the STPFaSL instrument by topic before and after 


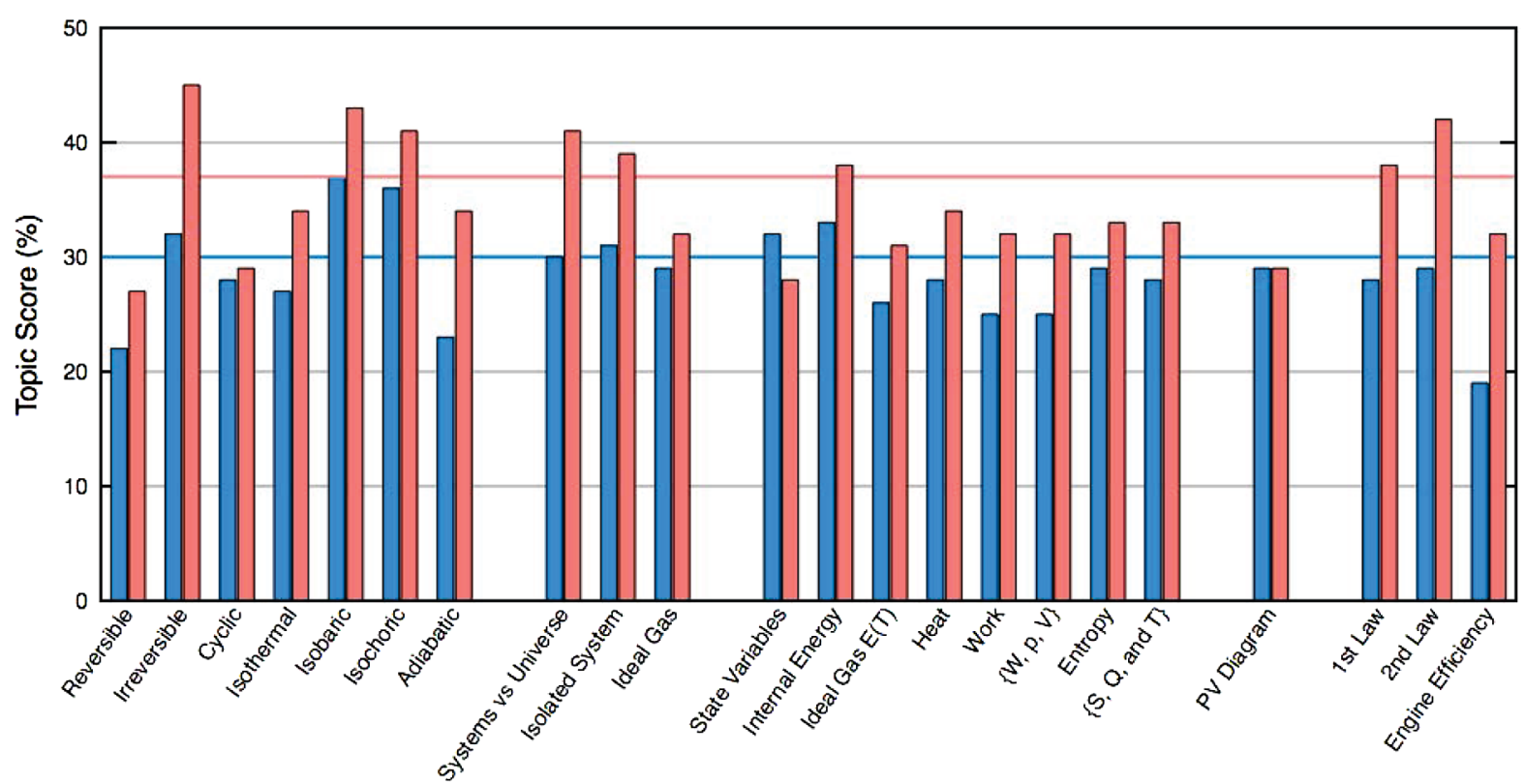

FIG. 3. Average percentage scores for students in algebra-based introductory physics courses on the STPFaSL instrument by topic before and after instruction (for the pretest, the number of students $N=218$, blue, and for the post-test, $N=382$, red). The blue and red horizontal lines show the averages on the entire survey instrument before and after instruction, respectively.

instruction. The combined average performance of upperlevel undergraduates and physics Ph.D. students in their first semester of the Ph.D. program on various concepts is shown in Fig. 5 and of Ph.D. students individually vs those in pairs in Fig. 6. Some of the conceptual difficulties displayed on the survey instrument include difficulty reasoning with multiple quantities simultaneously, difficulty in systematically applying various constraints (for an isothermal, adiabatic, isochoric, reversible, or irreversible process, isolated system, etc.), difficulty due to oversimplification of the first law and overgeneralization of the second law. As noted,

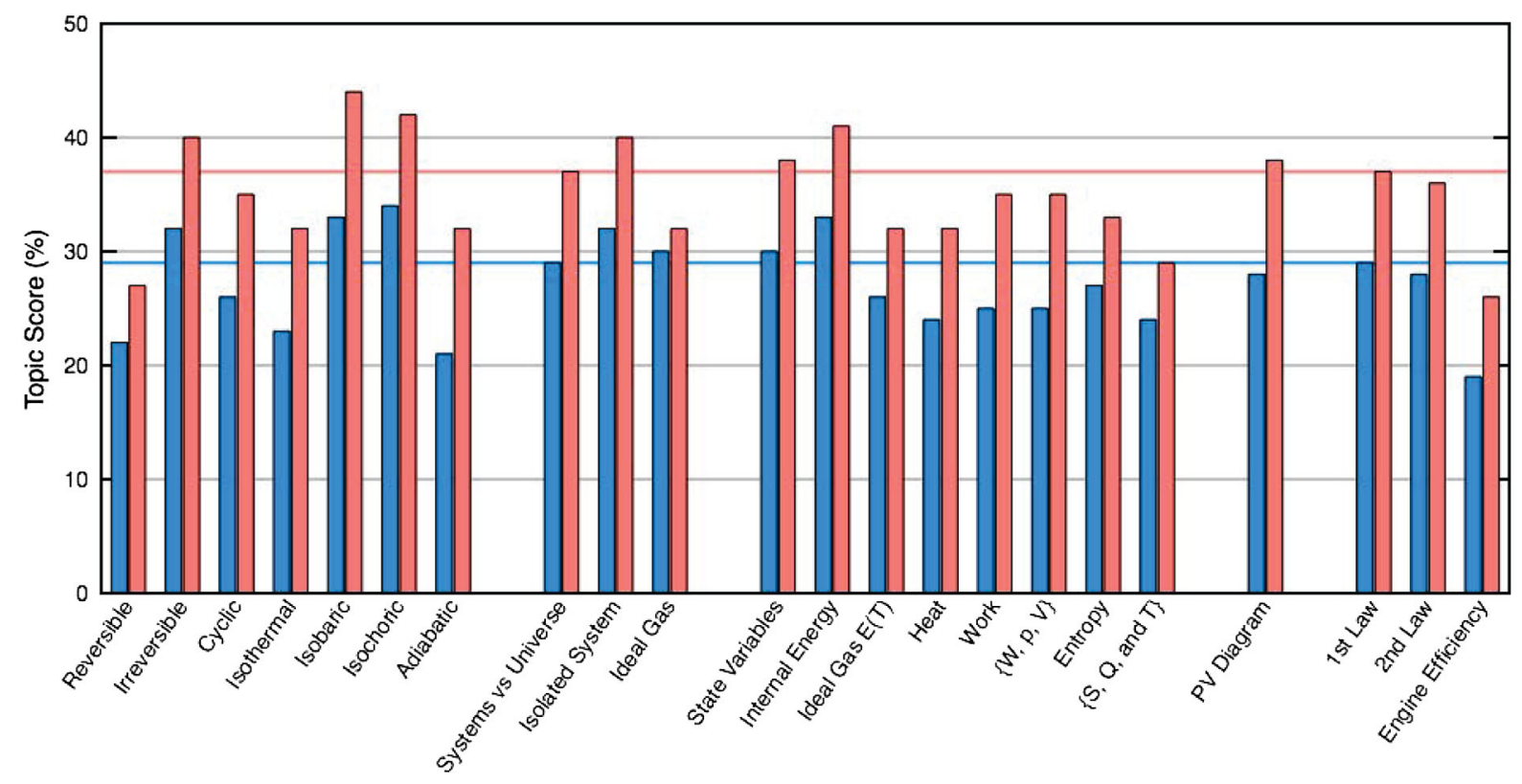

FIG. 4. Average percentage scores for students in calculus-based introductory physics courses on the STPFaSL instrument by topic before and after instruction (for the pretest, the number of students $N=704$, blue, and for the post-test, $N=505$, red). The blue and red horizontal lines show the averages on the entire survey instrument before and after instruction, respectively. 


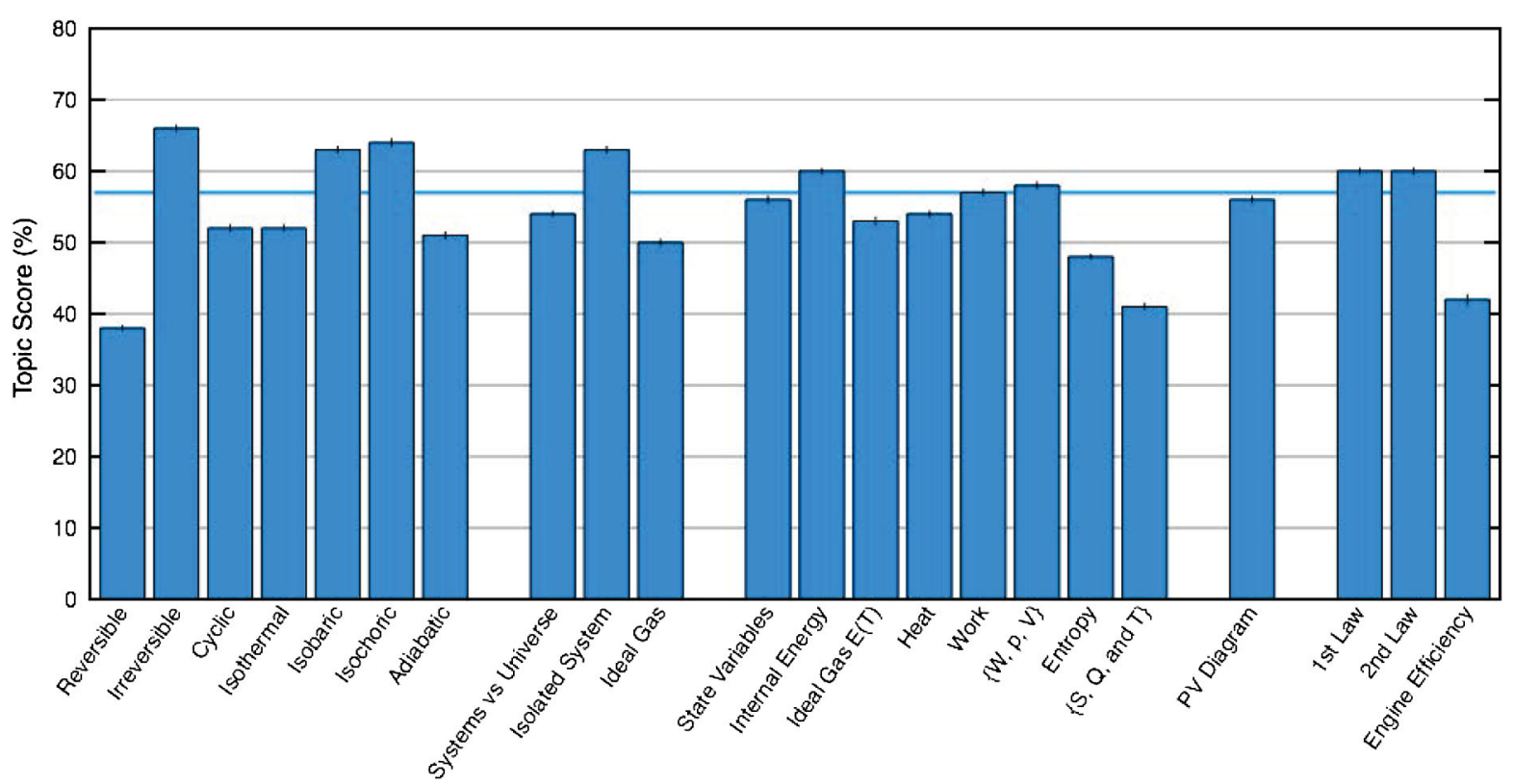

FIG. 5. Average performance on the STPFaSL instrument by topic for $N=147$ upper-level undergraduates and Ph.D. students. For completeness, error bars on each topic score (very small black vertical lines) indicate the sample error of the mean topic score, assuming each topic is independent. For comparing pairs of topics whose coverage on the STPFaSL instrument is minimally overlapping, e.g., comparison of performance on questions involving Irreversible and Reversible processes, an assumption of independence may be appropriate, but otherwise the topics and their errors should not be directly compared within a population. Another pair of topics for which there is minimal overlap involves the second law problems and problems requiring knowledge of the state variables. The blue horizontal line shows the average on the entire instrument.

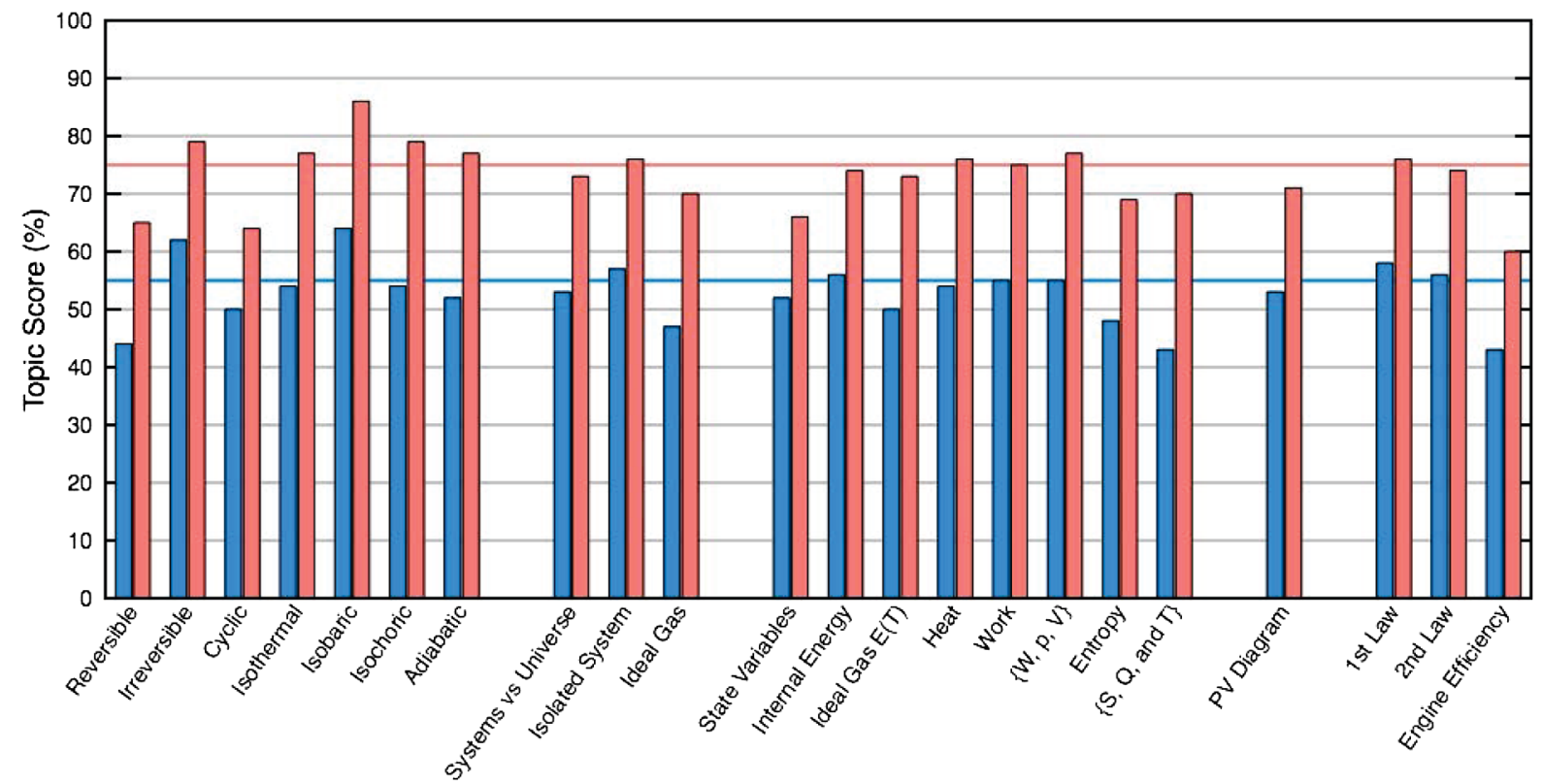

FIG. 6. Average percentage scores for first-year physics Ph.D. students individually and in pairs on the STPFaSL instrument by topic (for individual Ph.D. students, the number of students $N=45$, blue, and for the paired test, $N=21$, red). The blue and red horizontal lines show the averages for those groups on the entire survey instrument.

many of these difficulties were inspired and incorporated in the survey instrument based upon those that have been documented (see, e.g., Refs. [37-62]). Moreover, our findings with this validated survey instrument demonstrate the robustness of the previous findings, e.g., in Refs. [37-62], about student difficulties with these concepts. 


\section{SUMMARY}

We developed and validated and administered a 33-item conceptual multiple-choice survey instrument focusing on thermodynamic processes and the first and second laws at the level covered in introductory physics courses called the survey of thermodynamic processes and first and second laws (STPFaSL). The survey instrument uses the common difficulties found in the previous studies and additional data from written responses and interviews as a guide. The concepts related to thermodynamic processes and the first and second laws focusing on topics covered in an introductory physics course turned out to be challenging even for advanced students who were administered the survey instrument for obtaining baseline data and for evaluating content validity. The STPFaSL instrument is designed to measure the effectiveness of traditional and/or researchbased approaches for helping introductory students learn these thermodynamics concepts covered in the survey for a group of students. The average individual scores on the survey instrument from traditionally taught classes at various institutions included in this study are low. We note that the average scores for other conceptual survey instruments for traditionally taught introductory classes are also low, e.g., for the BEMA [19], the post-test scores for introductory students range from $23 \%$ to $45 \%$, and for the CSEM [20], the scores range from $25 \%$ to $47 \%$. The low scores even after instruction indicate that the traditional instructional approach using lectures alone is ineffective in helping students learn these concepts. The STPFaSL survey instrument can be used to measure the effectiveness of instruction in these topics using a research-based pedagogy.

\section{ACKNOWLEDGMENTS}

We are extremely indebted to David Meltzer and Mike Loverude for providing very extensive feedback on several versions of the survey instrument. We thank all faculty members and students from all six institutions who helped during the development and validation of the survey instrument and/or administered the final version to their classes. We also thank the anonymous reviewers.
[1] F. Reif, Millikan Lecture 1994: Understanding and teaching important scientific thought processes, Am. J. Phys. 63, 17 (1995).

[2] C. Singh, When physical intuition fails, Am. J. Phys. 70, 1103 (2002).

[3] C. Singh, Assessing student expertise in introductory physics with isomorphic problems. I. Performance on a nonintuitive problem pair from introductory physics, Phys. Rev. ST Phys. Educ. Res. 4, 010104 (2008).

[4] C. Singh, Assessing student expertise in introductory physics with isomorphic problems. II. Effect of some potential factors on problem solving and transfer, Phys. Rev. ST Phys. Educ. Res. 4, 010105 (2008).

[5] S. Y. Lin and C. Singh, Using isomorphic problems to learn introductory physics, Phys. Rev. ST Phys. Educ. Res. 7, 020104 (2011).

[6] E. Yerushalmi, E. Cohen, A. Mason, and C. Singh, What do students do when asked to diagnose their mistakes? Does it help them? I. An atypical quiz context, Phys. Rev. ST Phys. Educ. Res. 8, 020109 (2012).

[7] E. Yerushalmi, E. Cohen, A. Mason, and C. Singh, What do students do when asked to diagnose their mistakes? Does it help them? II. A more typical quiz context, Phys. Rev. ST Phys. Educ. Res. 8, 020110 (2012).

[8] S. Y. Lin and C. Singh, Using isomorphic problem pair to learn introductory physics: Transferring from a two-step problem to a three-step problem, Phys. Rev. ST Phys. Educ. Res. 9, 020114 (2013).

[9] S. Y. Lin and C. Singh, Effect of scaffolding on helping introductory physics students solve quantitative problems involving strong alternative conceptions, Phys. Rev. ST Phys. Educ. Res. 11, 020105 (2015).

[10] A. Maries, S. Y. Lin, and C. Singh, Challenges in designing appropriate scaffolding to improve students' representational consistency: The case of a Gauss's law problem, Phys. Rev. Phys. Educ. Res. 13, 020103 (2017).

[11] A. Maries and C. Singh, Case of two electrostatics problems: Can providing a diagram adversely impact introductory physics students' problem solving performance?, Phys. Rev. Phys. Educ. Res. 14, 010114 (2018).

[12] D. Hestenes, M. Wells, and G. Swackhamer, Force Concept Inventory, Phys. Teach. 30, 141 (1992).

[13] R. Hake, Interactive-engagement versus traditional methods: A six-thousand-student survey of mechanics test data for introductory physics courses, Am. J. Phys. 66, 64 (1998).

[14] V. Coletta and J. Phillips, Interpreting FCI scores: Normalized gain, preinstruction scores, and scientific reasoning ability, Am. J. Phys. 73, 1172 (2005).

[15] R. Beichner, Testing student interpretation of kinematics graphs, Am. J. Phys. 62, 750 (1994).

[16] C. Singh and D. Rosengrant, Multiple-choice test of energy and momentum concepts, Am. J. Phys. 71, 607 (2003).

[17] K. Mashood and V. Singh, Rotational kinematics of a rigid body about a fixed axis: development and analysis of an inventory, Eur. J. Phys. 36, 045020 (2015).

[18] L. Rimoldini and C. Singh, Student understanding of rotational and rolling motion concepts, Phys. Rev. ST Phys. Educ. Res. 1, 010102 (2005).

[19] L. Ding, R. Chabay, B. Sherwood, and R. Beichner, Valuating an assessment tool: Brief electricity and 
magnetism assessment, Phys. Rev. ST Phys. Educ. Res. 2, 010105 (2006).

[20] D. Maloney, T. O'Kuma, C. Hieggelke, and A. Van Heuvelen, Surveying students' conceptual knowledge of electricity and magnetism, Am. J. Phys. Supp. 69, s12 (2001).

[21] C. Singh, Improving students' understanding of magnetism, in Proceedings of the 2008 Annual Conference \& Exposition, Pittsburgh, Pennsylvania, https://peer.asee.org/3117 arXiv:1701.01523v1, pp. 1-16 (2008).

[22] J. Li and C. Singh, Developing a magnetism conceptual survey and assessing gender differences in student understanding of magnetism, AIP Conf. Proc. 1413, 43 (2012).

[23] J. Li and C. Singh, Developing and validating a conceptual survey to assess introductory physics students' understanding of magnetism, Eur. J. Phys. 38, 025702 (2017).

[24] P. Engelhardt and R. Beichner, Students' understanding of direct current resistive electrical circuits, Am. J. Phys. 72, 98 (2004).

[25] C. Singh, Student understanding of symmetry and Gauss's law of electricity, Am. J. Phys. 74, 923 (2006).

[26] C. Singh, Student understanding of symmetry and Gauss's law, AIP Conf. Proc. 790, 65 (2005).

[27] R. Thornton and D. Sokoloff, Heat and Temperature Conceptual Evaluation (HTCE) (2001).

[28] https://www.physport.org/assessments.

[29] S. Yeo and M Zadnik, Introductory Thermal Concept Evaluation: Assessing students' understanding (TCE), Phys. Teach. 39, 496 (2001).

[30] H. Chu, D. Treagust, S. Yeo, and M. Zadnik, Evaluation of students' understanding of thermal concepts in everyday contexts, Int. J. Sci. Educ. 34, 1509 (2012).

[31] P. Wattanakasiwich, P. Taleab, M. Sharma, and I. Johnston, Development and implementation of a conceptual survey in thermodynamics, Int. J. Innov. Sci. Math. Educ. 21, 29 (2013).

[32] K. Midkiff, T. Litzinger, and D. Evans, Development of engineering thermodynamics concept inventory instruments, in 31st ASEE/IEEE Frontier in Education Conference, Reno, NV, 2001.

[33] R. Steveler, R. Miller, R. Santiago, M. Nelson, M. Geist, and B. Olds, Rigorous methodology for concept inventory development: Using the assessment triangle to develop and test the Thermal and Transport Science Concept Inventory (TTCI), Int. J. Eng. Educ. 27, 968 (2011).

[34] P. Engelhardt, An introduction to Classical Test Theory as applied to conceptual multiple-choice tests, in Getting Started in PER, edited by C. Henderson and K. Harper (AAPT, College Park, MD, 2009), Reviews in PER, Vol. 2.

[35] P. Kline, A Handbook of Test Construction: Introduction to Psychometric Design (Methuen, London, 1986).

[36] J. Nunnally and I. Bernstein, Psychometric Theory, 3rd ed. (McGraw Hill, New York, 1994).

[37] B. Dreyfus, B. Geller, D. Meltzer, and V. Sawtelle, Resource letter TTSM-1: Teaching thermodynamics and statistical mechanics in introductory physics, chemistry, and biology, Am. J. Phys. 83, 5 (2015).

[38] M. Loverude, C. Kautz, and P. Heron, Student understanding of the first law of thermodynamics: Relating work to the adiabatic compression of an ideal gas, Am. J. Phys. 70, 137 (2002).

[39] D. Meltzer, Investigation of students' reasoning regarding heat, work, and the first law of thermodynamics in an introductory calculus-based general physics course, Am. J. Phys. 72, 1432 (2004).

[40] C. Kautz, P. Heron, M. Loverude, and L. McDermott, Student understanding of the ideal gas law, Part i: A macroscopic perspective, Am. J. Phys. 73, 1064 (2005).

[41] M. Cochran and P. Heron, Development and assessment of research-based tutorials on heat engines and the second law of thermodynamics, Am. J. Phys. 74, 734 (2006).

[42] B. Bucy, J. Thompson, and D. Mountcastle, What is entropy? Advanced undergraduate performance comparing ideal gas processes, AIP Conf. Proc. 818, 81 (2006).

[43] W. Christensen, D. Meltzer, and C. Ogilvie, Student ideas regarding entropy and the second law of thermodynamics in an introductory physics course, Am. J. Phys. 77, 907 (2009).

[44] T. Smith, W. Christensen, D. Mountcastle, and J. Thompson, Identifying student difficulties with heat engines, entropy, and the Carnot cycle, Phys. Rev. ST Phys. Educ. Res. 11, 020116 (2015).

[45] M. Malgieri, P. Onorato, A. Valentini, and A. De Ambrosis, Improving the connection between the microscopic and macroscopic approaches to thermodynamics in high school, Phys. Educ. 51, 065010 (2016).

[46] C. Kautz and G. Schmitz, Probing student understanding of basic concepts and principles in introductory engineering thermodynamics, in Proceedings of the ASME 2007 International Mechanical Engineering Congress and Exposition (American Society of Mechanical Engineers, 2007), p. 473.

[47] P. Thomas and R. Schwenz, College physical chemistry students' conceptions of equilibrium and fundamental thermodynamics, J. Res. Sci. Teach. 35, 1151 (1998).

[48] E. Langbeheim, S. Safran, S. Livne, and E. Yerushalmi, Evolution in students' understanding of thermal physics with increasing complexity, Phys. Rev. ST Phys. Educ. Res. 9, 020117 (2013).

[49] R. Leinonen, M. Asikainen, and P. Hirvonen, University students explaining adiabatic compression of an ideal gas - a new phenomenon in introductory thermal physics, Res. Sci. Educ. 42, 1165 (2012).

[50] R. Leinonen, E. Räsänen, M. Asikainen, and P. Hirvonen, Students' pre-knowledge as a guideline in the teaching of introductory thermal physics at university, Eur. J. Phys. 30, 593 (2009).

[51] D. Meltzer, Observations of general learning patterns in an upper-level thermal physics course, AIP Conf. Proc. 1179, 31 (2009).

[52] K. Bain, A. Moon, M. Mack, and M. Towns, A review of research on the teaching and learning of thermodynamics at the university level, Chem. Educ. Res. Pract. 15, 320 (2014).

[53] H. Goldring and J. Osborne, Students' difficulties with energy and related concepts, Phys. Educ. 29, 26 (1994).

[54] J. Clark, J. Thompson, and D. Mountcastle, Comparing student conceptual understanding of thermodynamics in physics and engineering, AIP Conf. Proc. 1513, 102 (2013). 
[55] T. Smith, D. Mountcastle, and J. Thompson, Student understanding of the Boltzmann factor, Phys. Rev. ST Phys. Educ. Res. 11, 020123 (2015).

[56] M. Granville, Student misconceptions in thermodynamics, J. Chem. Educ. 62, 847 (1985).

[57] T. Smith, D. Mountcastle, and J. Thompson, Identifying student difficulties with conflicting ideas in statistical mechanics, AIP Conf. Proc. 1513, 386 (2013).

[58] T. Nilsson and $H$. Niedderer, An analytical tool to determine undergraduate students' use of volume and pressure when describing expansion work and technical work, Chem. Educ. Res. Pract. 13, 348 (2012).

[59] D. Meltzer, Investigation of student learning in thermodynamics and implications for instruction in chemistry and engineering, AIP Conf. Proc. 883, 38 (2007).

[60] J. Bennett and M. Sözbilir, A study of Turkish chemistry undergraduates' understanding of entropy, J. Chem. Educ. 84, 1204 (2007).
[61] H. Georgio and M. Sharma, Does using active learning in thermodynamics lectures improve students' conceptual understanding and learning experiences?, Eur. J. Phys. 36, 015020 (2015).

[62] R. Leinonen, M. Asikainen, and P. Hirvonen, Overcoming students' misconceptions concerning thermal physics with the aid of hints and peer interaction during a lecture course, Phys. Rev. ST Phys. Educ. Res. 9, 020112 (2013).

[63] See Supplemental Material at http://link.aps.org/ supplemental/10.1103/PhysRevPhysEducRes.17.010104 for the STPFaSL test and key.

[64] A. Tongchai, M. Sharma, I Johnston, K. Arayathanitkul, and C. Soankwan, Consistency of students' conceptions of wave propagation: Findings from a conceptual survey in mechanical waves, Phys. Rev. ST Phys. Educ. Res. 7, 020101 (2020). 